\title{
Transcriptomic analysis of the lesser spotted catshark (Scyliorhinus canicula) pancreas, liver and brain reveals molecular level conservation of vertebrate pancreas function
}

\author{
John F Mulley ${ }^{1 *}$, Adam D Hargreaves ${ }^{1}$, Matthew J Hegarty ${ }^{2}$, R Scott Heller ${ }^{3}$ and Martin T Swain ${ }^{2}$
}

\begin{abstract}
Background: Understanding the evolution of the vertebrate pancreas is key to understanding its functions. The chondrichthyes (cartilaginous fish such as sharks and rays) have often been suggested to possess the most ancient example of a distinct pancreas with both hormonal (endocrine) and digestive (exocrine) roles. The lack of genetic, genomic and transcriptomic data for cartilaginous fish has hindered a more thorough understanding of the molecular-level functions of the chondrichthyan pancreas, particularly with respect to their "unusual" energy metabolism (where ketone bodies and amino acids are the main oxidative fuel source) and their paradoxical ability to both maintain stable blood glucose levels and tolerate extensive periods of hypoglycemia. In order to shed light on some of these processes, we carried out the first large-scale comparative transcriptomic survey of multiple cartilaginous fish tissues: the pancreas, brain and liver of the lesser spotted catshark, Scyliorhinus canicula.
\end{abstract}

Results: We generated a mutli-tissue assembly comprising 86,006 contigs, of which 44,794 were assigned to a particular tissue or combination of tissues based on mapping of sequencing reads. We have characterised transcripts encoding genes involved in insulin regulation, glucose sensing, transcriptional regulation, signaling and digestion, as well as many peptide hormone precursors and their receptors for the first time. Comparisons to mammalian pancreas transcriptomes reveals that mechanisms of glucose sensing and insulin regulation used to establish and maintain a stable internal environment are conserved across jawed vertebrates and likely pre-date the vertebrate radiation. Conservation of pancreatic hormones and genes encoding digestive proteins support the single, early evolution of a distinct pancreatic gland with endocrine and exocrine functions in jawed vertebrates. In addition, we demonstrate that chondrichthyes lack pancreatic polypeptide (PP) and that reports of PP in the literature are likely due cross-reaction with PYY and/or NPY in the pancreas. A three hormone islet organ is therefore the ancestral jawed vertebrate condition, later elaborated upon only in the tetrapod lineage.

Conclusions: The cartilaginous fish are a great untapped resource for the reconstruction of patterns and processes of vertebrate evolution and new approaches such as those described in this paper will greatly facilitate their incorporation into the rank of "model organism".

Keywords: Catshark, Pancreas transcriptome, Pdx1, Pdx2, Insulin regulation, PYY, Pancreatic polypeptide

\footnotetext{
*Correspondence: j.mulley@bangor.ac.uk

${ }^{1}$ School of Biological Sciences, Bangor University, Brambell Building, Deiniol

Road, Bangor, Gwynedd LL57 2UW, United Kingdom

Full list of author information is available at the end of the article
} 


\section{Background}

Chondrichthyans (cartilaginous fish such as sharks, skates, rays (elasmobranchs) and chimeras (holocephalans)) are the most distant group relative to mammals such as ourselves to possess a distinct pancreatic gland containing multiple cell types with both endocrine and exocrine functions [1,2]. The more distant vertebrate lineages such as the jawless hagfish and lampreys (Figure 1) possess only small islet organs containing insulin- and somatostatinproducing endocrine cells and these islets lack any glucagon-producing cells or exocrine function [2-4]. The accumulation of multiple cell types into a single compact gland was an important step in pancreas evolution (and can be considered to be an evolutionary innovation) $[5,6]$ and it has been suggested that a switch from sensing gut-glucose to blood-glucose to establish a "stable inner milieu" via homeostatic mechanisms may have been an important factor in the evolution of a more complex glucose-dependent brain in vertebrates,

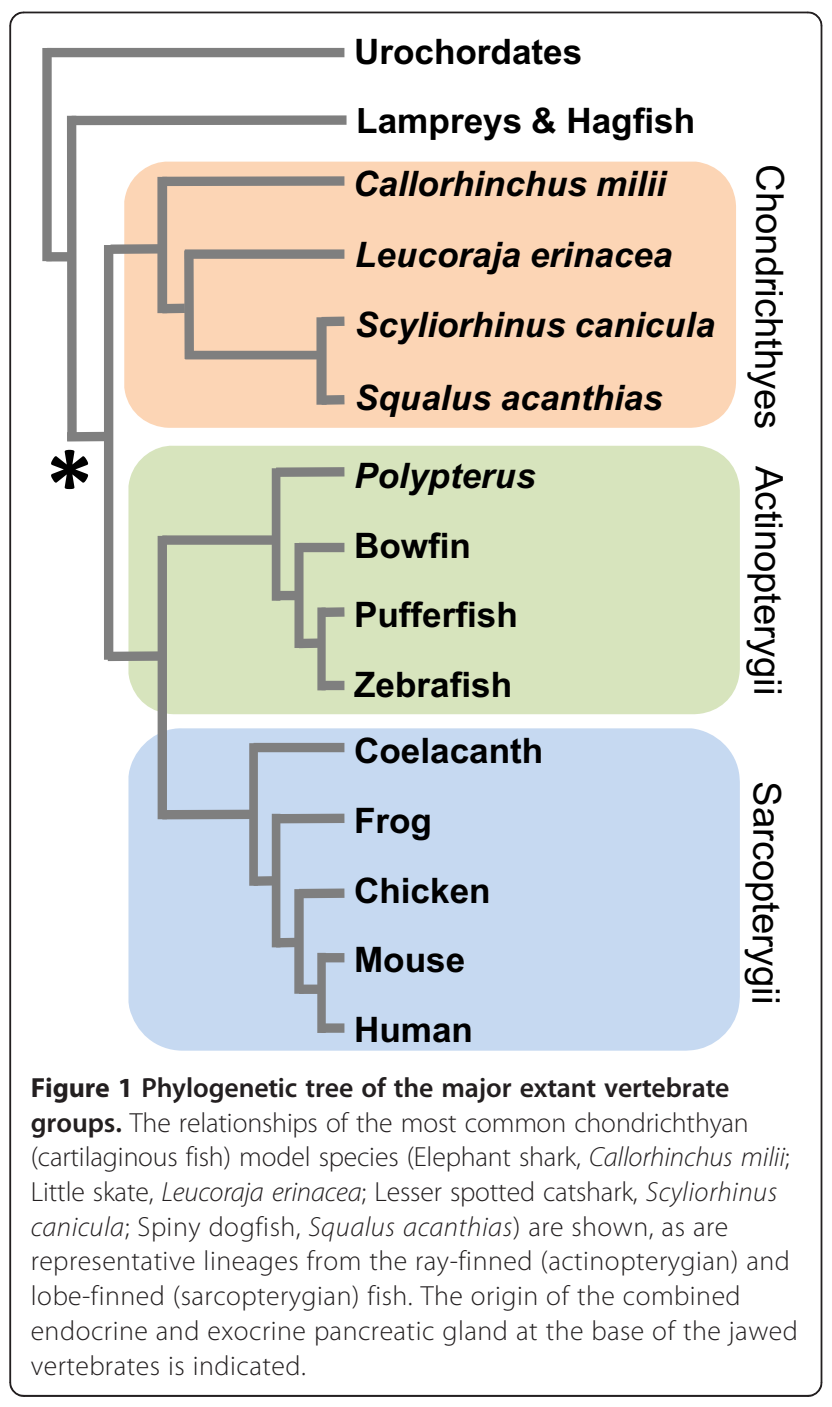

protected from hyper- and hypoglycaemia [7-9]. However, the fact that insulin-like peptides in insects seem to fulfil similar roles in glucose metabolism and other physiological processes such as growth and reproduction suggests that at least some elements of these mechanisms may have a more ancient origin [10].

Decades of research using light and electron microscopy and immunohistochemistry has revealed a great deal about the structure and organisation of the chondrichthyan pancreas and more recent studies have characterised the protein sequence and structure of some of the key pancreatic hormones [11-15]. The endocrine islets of chondrichthyans are typically scattered within exocrine tissue, sometimes associated with minor ducts and contain a number of distinct cell types, thought to include the four major pancreas cell types: $\alpha$-cells producing glucagon to increase blood glucose; $\beta$-cells producing insulin to reduce blood glucose; $\delta$-cells producing somatostatin to regulate pancreatic hormones such as insulin and glucagon and $\gamma$-cells producing pancreatic polypeptide [16-18]. In addition to structural, cellular and hormonal conservation of the chondrichthyan pancreas compared to other vertebrates, there is also a conservation of function, with glucose-sensitive insulin release [11], pancreatectomyinduced hyperglycemia $[19,20]$ and exogenous insulininduced hypoglycaemic effects [11,21-23]. However, although blood plasma glucose levels are maintained at a fairly constant level during feeding and fasting (even over periods of up to 150 days without food) $[21,24,25]$, actual plasma glucose levels in elasmobranchs are lower than in teleost fish of comparative size and with similar metabolic rates [26]. It has also been found that elasmobranchs have an impressive tolerance of hypoglycaemia, including an ability to cope with a virtual absence of circulating glucose for at least 24 hours, a $75 \%$ reduction for at least a week and subnormal plasma glucose levels for extended periods $[22,27]$. There is an obvious paradox associated with an impressive ability to cope with long periods of hypoglycaemia existing in conjunction with the maintenance of apparently stable plasma glucose levels and others have pondered the necessity of central glucose-sensing mechanisms in these species [26].

The chondrichthyan pancreas represents an important model for studies of vertebrate pancreas evolution and function, particularly with reference to glucose homeostasis. However, full analysis of these areas has been hindered by a lack of genetic information and resources - almost the entirety of our current understanding of the chondrichthyan pancreas is based on what might be considered somewhat "old fashioned" (although still vital, important and informative) biological techniques, including descriptive gross anatomy and light and electron microscopy, enzymatic assays typically involving the injection of peptides 
derived from other (often mammalian) species and immunohistochemistry involving the use of antibodies raised against short mammalian peptide epitopes (see [2,3,26,28] for reviews). There is currently a dearth of data regarding molecular level functions of the chondrichthyan pancreas, including mechanisms of transcriptional and translational control of gene regulation, signaling both in terms of cellcell communication within the pancreas and in terms of response to neuroendocrine signals and even more basic information such as the sequences of mRNA and protein precursors of previously identified or characterised digestive enzymes and pancreatic peptides.

The lesser spotted catshark (Scyliorhinus canicula, often referred to as the lesser spotted dogfish) has recently become the chondrichthyan model of choice for a wide range of genetic, developmental and evolutionary analyses [29] and transcriptomic and genomic sequencing projects are currently underway for this species at Genoscope (www.genoscope.cns.fr). An enigmatic second member of the Pancreas and duodenal homeobox ( $\mathrm{Pdx}$ ) gene family (called $P d x 2$ ) was recently identified in S. canicula [30] but further studies of the role of this gene or the identification of the presence of additional members of other gene families involved in pancreas development, cellspecification and insulin regulation are impossible without more comprehensive molecular analyses. In order to shed further light on the possible role of the $P d x 2$ gene and to go some way to addressing the current dearth of data we set out to determine the pancreas transcriptome of the lesser spotted catshark and to carry out comparative expression analyses with other adult body tissues (brain and liver). The brain and pancreas share homology as elements of the neuroendocrine system and so can reasonably be expected to show a greater degree of similarity in gene expression to each other than to other tissues. The pancreas also has an exocrine (digestive) role and arises from an adjacent region of the developing foregut to the liver, which also has a digestive role. These data represent the first large-scale transcriptomic analysis of multiple cartilaginous fish tissues and will be invaluable in understanding the functions of the cartilaginous fish pancreas, as well as shedding light on the evolution of the vertebrate pancreas itself.

\section{Results}

A total of $6,260,398 ; 32,106,318$ and $12,201,682$ pairedend sequencing reads were generated for the pancreas, liver and brain respectively and these were pooled to generate a single assembly which contained 86,006 contigs (when trimmed to remove all contigs $<300 \mathrm{bp}$, which likely represent single pairs of sequencing reads). The tissue distribution of these transcripts was determined by mapping sequencing reads from each tissue to this assembly and abundance values of $\geq 1$ fragments per kilobase per million mapped reads (FPKM) were taken to confirm expression of a particular transcript in each tissue (Table 1 ). In this way 44,794 contigs were assigned to one or more tissues (Figure 2). All transcripts contained an ORF encoding 20 amino acids or more (Figure 3), of which roughly 4-7\% encoded a signal peptide and so are likely to be secreted (Table 1). Typically, between 15-53\% of transcripts had a BLAST hit in the RefSeq collection and $12-49 \%$ were annotated with GO terms (Table 2). Although low, these figures are broadly comparable with a similar analysis of the white shark heart transcriptome [31], which found matches of $23.5 \%$ and $21.5 \%$, respectively. In order to provide a broad overview of the assigned gene ontology terms, we carried out a generic GOSlim annotation of the data (Figures 4 and 5), and Fishers exact tests showed that the pancreas was enriched for seven GO terms compared to liver ('cell', 'reproduction', 'transcription, DNA-dependent', 'embryo development', 'growth', 'intracellular non-membrane-bounded organelle' and 'non-membranebounded organelle') and two terms compared to brain ('transcription, DNA-dependent' and 'cellular amino acid metabolic process' - the full comparative enrichment results are provided in Additional file 1).

A more detailed search strategy was carried out for particular categories of genes that would shed light on the similarities or differences of pancreas function in $S$.

Table 1 Assembly characteristics

\begin{tabular}{|c|c|c|c|c|c|c|}
\hline Tissue(s) & $\begin{array}{c}\text { Number of } \\
\text { contigs }>300 \text { bp }\end{array}$ & Contig N50 (bp) & Longest contig (bp) & $\begin{array}{l}\text { Mean ORF } \\
\text { length (bp) }\end{array}$ & $\begin{array}{c}\text { Max ORF } \\
\text { length (bp) }\end{array}$ & $\begin{array}{c}\text { Number ORFs } \\
\text { with signal peptide }\end{array}$ \\
\hline Pancreas only & 6551 & 429 & 5386 & 177 & 3005 & $257(3.92 \%)$ \\
\hline Brain only & 21241 & 798 & 16085 & 338 & 13751 & $1029(4.84 \%)$ \\
\hline Liver only & 3423 & 676 & 13906 & 271 & 13532 & $220(6.43 \%)$ \\
\hline Pancreas, brain & 3847 & 1479 & 10710 & 482 & 10394 & $210(5.46 \%)$ \\
\hline Pancreas, liver & 924 & 1039 & 5907 & 329 & 4505 & $62(6.71 \%)$ \\
\hline Brain, liver & 2482 & 1329 & 12080 & 481 & 10403 & 149 (6.00\%) \\
\hline Pancreas, liver, brain & 6326 & 2257 & 11135 & 705 & 9329 & $356(5.63 \%)$ \\
\hline
\end{tabular}

Tissue distribution of transcripts was assigned by read mapping, taking a value of $\geq 1$ fragments per kilobase per million mapped reads (FPKM) as evidence of expression. 


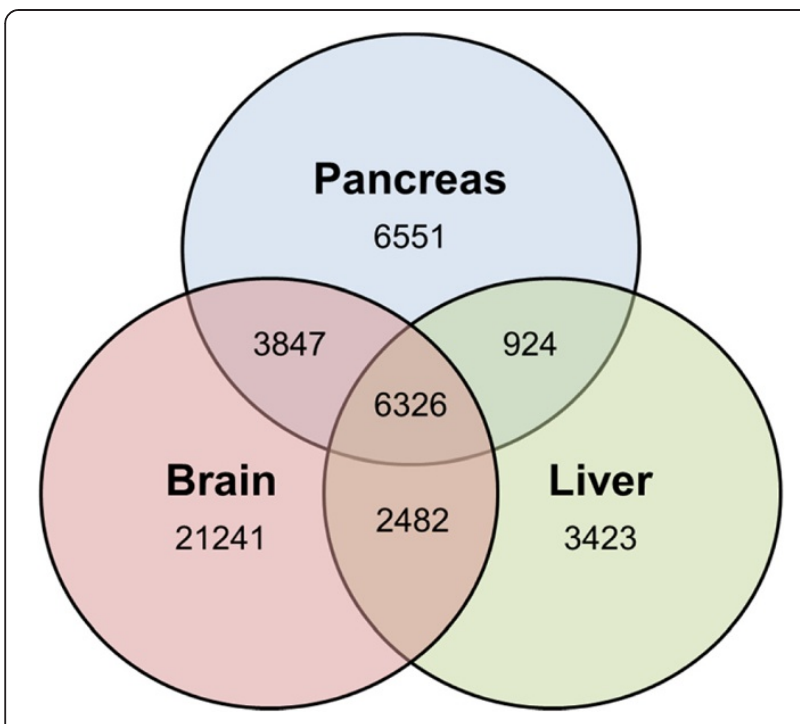

Figure 2 Tissue distribution of transcripts, as determined by mapping the sequencing reads derived from each tissue to a combined, all-tissue assembly. Contig values of $\geq 1$ FPKM (Fragments Per Kilobase of exon per Million fragments mapped) were taken as evidence for expression.

canicula compared to other vertebrates. The results of these analyses are outlined in the following sections.

\section{Pancreatic hormones and their receptors}

A large amount of immunohistochemical research has putatively identified the presence of a number of pancreatic peptide hormones in cartilaginous fish, including insulin, glucagon, somatostatin and pancreatic polypeptide, and the presence of at least some of these peptides has been confirmed by proteomic studies [11,12,15,32]. Our transcriptomic data confirms the presence of mRNA transcripts encoding preproinsulin, preproglucagon (Figure 6) and preprosomatostatin (corresponding to the $\mathrm{SSa}$ gene [33]) in the pancreas and preprosomatostatin b and c in both the brain and pancreas, but not pancreatic polypeptide (PP - see next section), gastrin, gastric inhibitory polypeptide (GIP) or secretin. Amylin (islet amyloid polypeptide) is expressed in only brain and liver, vasoactive intestinal polypeptide (VIP) is expressed by both pancreas and brain, cholecystokinin by only brain and, as previously suggested [3], ghrelin appears to be absent from the shark pancreas and, indeed, from all three tissues. We find transcripts encoding the insulin receptor (IR) only in brain, the glucagon receptor only in liver and somatostatin receptor 1 (SSTR1) and SSTR5 in brain and both pancreas and brain respectively. Contrary to the findings of Larsson et al. [34], we find Neuropeptide Y receptors Y1, Y5 and Y6 in brain only and Y8 in both pancreas and brain, suggesting that the expression of these receptors either varies between chondrichthyan species, or is more dynamic than previously assumed.

The presence of PP and $\gamma$-cells are key aspects of current schemes for the mode of vertebrate pancreas evolution [1-3,35]. However, it has been known for some time that PP is tetrapod-specific, produced via duplication of the Peptide $Y Y$ gene sometime prior to the divergence of this lineage [36,37] and there is therefore a discrepancy between the findings of decades of immunohistochemical research and data from molecular genetic studies and analyses of vertebrate whole genome sequences. We have identified transcripts of two members of the Neuropeptide $Y$ family (which includes Neuropeptide Y (NPY), Peptide YY (PYY) and Pancreatic polypeptide (PP)) in our dataset - a $P Y Y$ gene expressed in pancreas and brain and a NPY gene expressed only in brain (Figure 7, both sequences are identical to published catshark sequences for PYY and NPY (accessions P69095 [38], AAB23237 [14]). We therefore suggest that older immunohistochemical studies which claimed to have detected PP+ cells in the cartilaginous fish pancreas may have in fact been relying on antisera that cross-

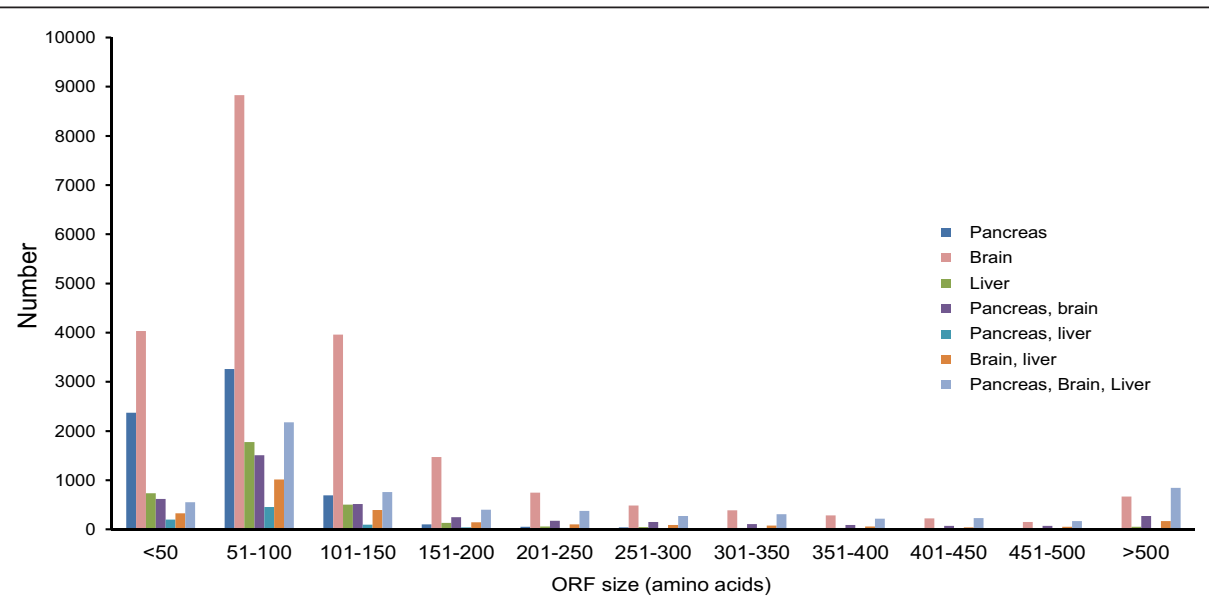

Figure 3 Length and tissue distribution of open reading frames (ORFs) derived from assembled contigs. 
Table 2 Number of contigs with a BLAST hit in the RefSeq database and gene ontology (GO) annotation assigned by BLAST2GO [124,125]

\begin{tabular}{|c|c|c|c|c|}
\hline & $\begin{array}{c}\text { Number contigs with } \\
\text { BLAST hit }\end{array}$ & $\begin{array}{c}\text { Number contigs with GO } \\
\text { annotation }\end{array}$ & $\begin{array}{l}\text { Number of transcription } \\
\text { factors }\end{array}$ & $\begin{array}{l}\text { Number of signaling pathway } \\
\text { components }\end{array}$ \\
\hline \multirow{2}{*}{ Pancreas only } & 998 & 766 & 13 & 38 \\
\hline & $(15 \%)$ & $(12 \%)$ & & \\
\hline \multirow{2}{*}{ Brain only } & 8093 & 6740 & 145 & 359 \\
\hline & $(38 \%)$ & $(32 \%)$ & & \\
\hline \multirow{2}{*}{ Liver only } & 830 & 661 & 12 & 37 \\
\hline & $(24 \%)$ & (19\%) & & \\
\hline \multirow{2}{*}{ Pancreas, brain } & 1640 & 1412 & 33 & 104 \\
\hline & $(43 \%)$ & $(37 \%)$ & & \\
\hline \multirow{2}{*}{ Pancreas, liver } & 249 & 200 & 14 & 11 \\
\hline & $(27 \%)$ & $(22 \%)$ & & \\
\hline \multirow{2}{*}{ Brain, liver } & 1019 & 909 & 10 & 83 \\
\hline & $(41 \%)$ & $(37 \%)$ & & \\
\hline \multirow{2}{*}{$\begin{array}{l}\text { Pancreas, liver, } \\
\text { brain }\end{array}$} & 3380 & 3141 & 51 & 187 \\
\hline & (53\%) & (49\%) & & \\
\hline
\end{tabular}

The number of transcription factors and signaling pathway components in each tissue or tissue combination is also shown.

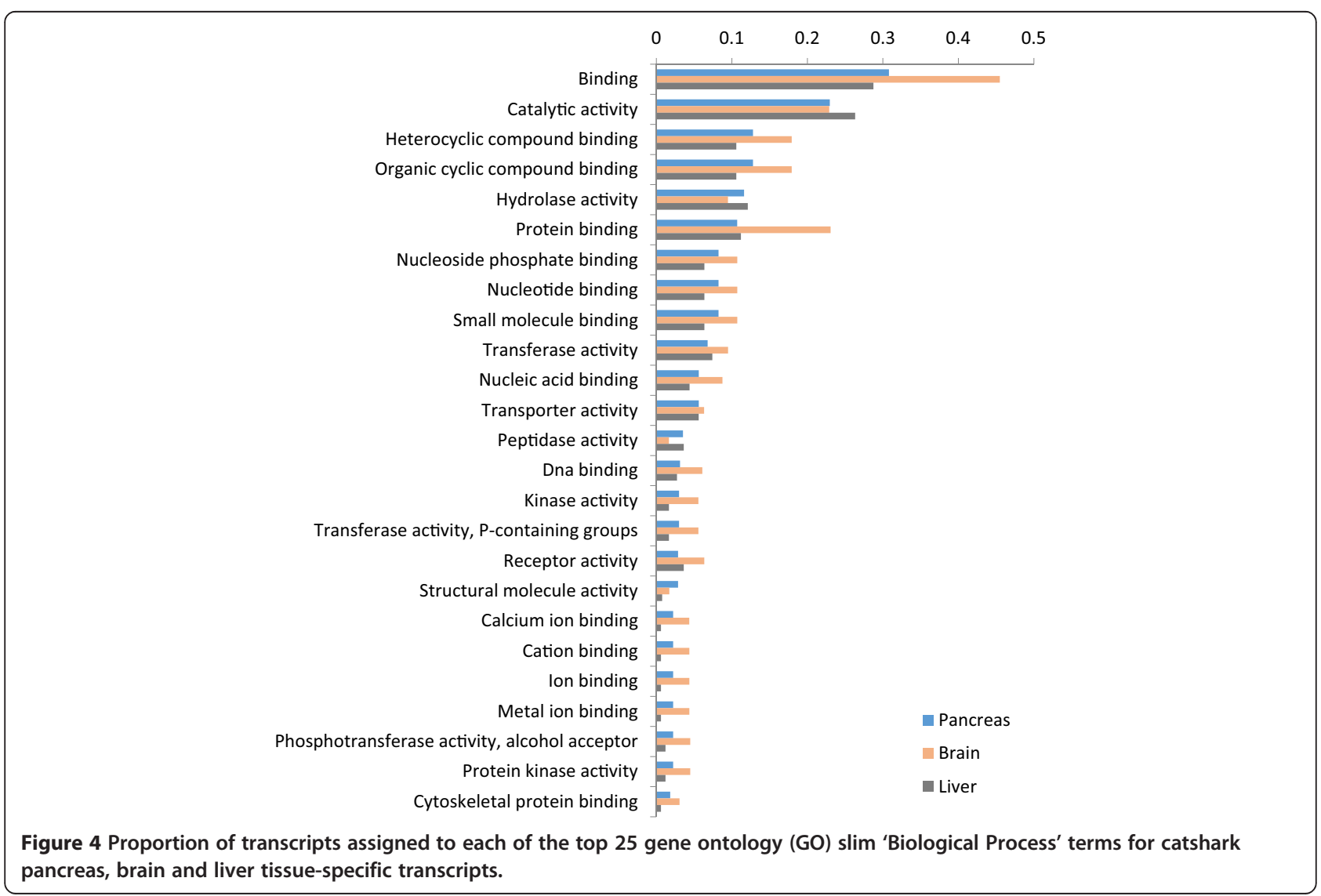




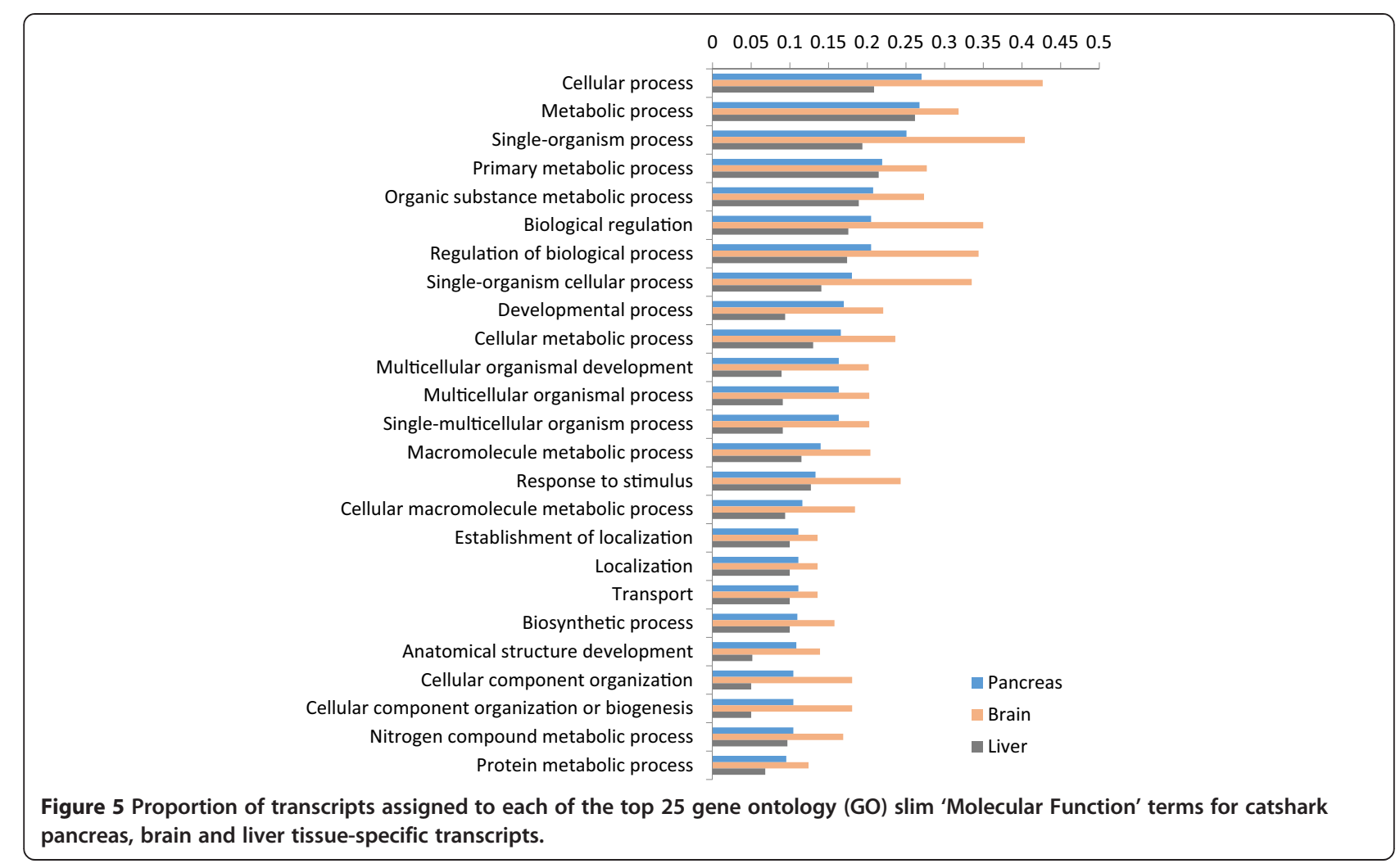

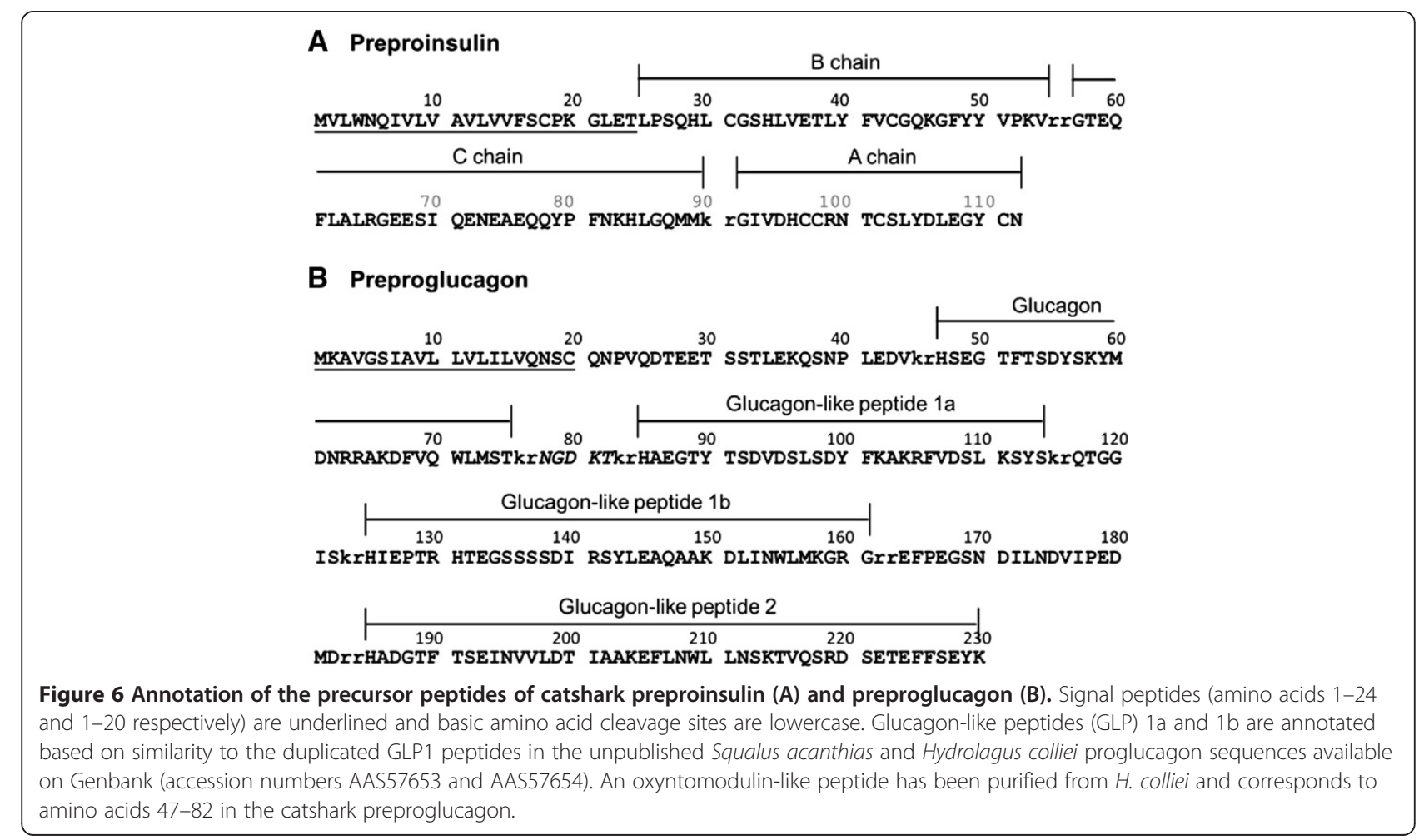




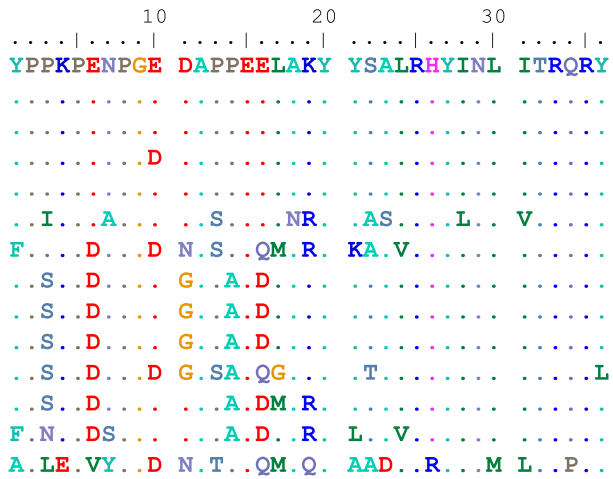

Figure 7 Amino acid alignment of vertebrate Peptide YY (PYY), Neuropeptide Y (NPY) and Pancreatic polypeptide (PP) sequences. Genbank accession numbers are given in square brackets. Sca, Scyliorhinus canicula (lesser spotted catshark); Sac, Squalus acanthias (spiny dogfish); Ler, Leucoraja erinacea (little skate); Cmi, Callorhinchus milii (elephant shark); Hsa, Homo sapiens (human); Lfl, Lampetra planeri (brook lamprey); Loc, Leucoraja ocellata (winter skate).

reacted with PYY. A focus on the (often brief) methods sections of several key historical papers revealed that they in fact used the same anti-PP antibody, produced by Ronald Chance at Eli Lily in the 1970's [16,39,40]. It therefore appears that this antibody was detecting PYY in the pancreas of cartilaginous fish and that these initial papers and various subsequent papers have repeatedly been cited until the presence of PP in cartilaginous fish is considered to be established fact. In other cases, the misidentification of sequenced peptides has added to the confusion [38].

Our immunohistochemical surveys of the catshark pancreas using high-affinity anti-PP antibodies (Additional file 2: Table S1) showed varying results. The PP antisera from Sigma weakly stained the catshark pancreas but the staining was completely absorbed with PP, NPY and PYY peptides (Figure 8). While the Millipore anti-PP failed to stain (except on the mouse control pancreas, data not shown), experiments with anti-PYY antibodies detected strong signals, co-localising with insulin but not glucagon or somatostatin (Figure 8). NPY antisera immunoreactivity was detected in the same pattern as PYY (data not shown) and was absorbed with either PYY or NPY peptides (Additional file 2: Table S2).

A search of the Blast2GO results for the term 'Hormone activity' identifies three other peptide-encoding transcripts expressed in the catshark pancreas: Gastrinreleasing peptide (GRP, in pancreas and brain), which fulfils a variety of roles in the gastrointestinal tract, including the regulation of hormone release and the secretion of pancreatic enzymes [41,42]; Neuromedin $\mathrm{U}$ (NMU, in all three tissues) which is expressed in nerves throughout the gastrointestinal tract [43] and Enkephalin (in pancreas and brain), an endogenous opioid that functions as a neurotransmitter or neuromodulator $[44,45]$.

\section{Glucose sensing}

Hexokinase type IV, more typically called Glucokinase (GK), is a glucose-phosphorylating enzyme that has been shown to be the key molecule for glucose sensing in mammalian liver and pancreas cells [46] and mutations in $G K$ are known to cause Maturity Onset Diabetes of the Young Type II (MODY2) [47,48]. Somewhat surprisingly, we find that $G K$ is expressed in the shark brain and glucokinase regulatory protein (GKRP) only in liver. We also identified transcripts in all three tissues corresponding to 6-phosphofructo-2-kinase/fructose-2,6bisphosphatase 2 (Pfkfb2), another regulator of glucose metabolism via interaction with GK. Finally we detected transcripts encoding two glucose transporters in all three tissues, namely the solute carrier family 2 genes Glut1 and Glut2 and the shark pancreas therefore appears to represent an ancestral state where both types of transporter are expressed in the pancreas, as opposed to the human pancreas (which relies on GLUT1) and that of rodents (which rely more heavily on Glut2) [49-51].

\section{Insulin regulation}

The regulation of the insulin gene has, for obvious reasons, been an area of intensive study and a number of key regulators are now known from studies in rodents and humans. Perhaps one of the most important is the Pancreas and duodenal homeobox $1(P d x 1)$ gene, also called Insulin promoter factor 1 (Ipf1), Islet/duodenum homeobox 1 (Idx1) or Somatostatin transactivating factor 1 (Stf1) [52-54] which (in addition to roles in embryonic development and $\beta$-cell specification) binds to the TAAT motif-containing A boxes of the mammalian insulin promoter to stimulate transcription [55-58]. Mutations in PDX1 have been linked to Maturity Onset Diabetes of the Young Type IV (MODY4) [59] and pancreatic agenesis $[60,61]$. Cartilaginous fish and coelacanths have previously 

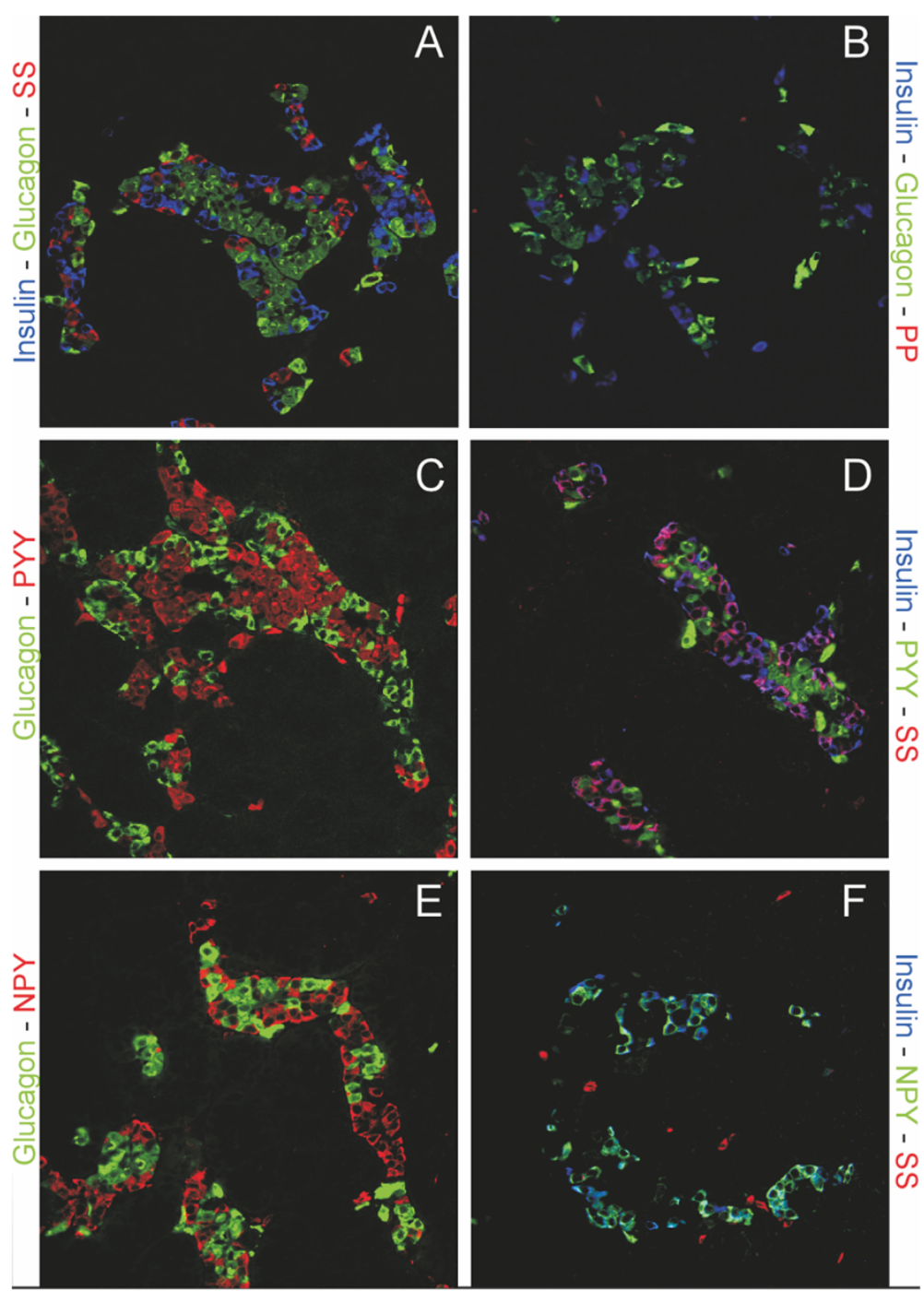

Figure 8 Immunolocalization of pancreatic hormones and pancreatic polypeptide and PYY in catshark pancreas. (A) The distribution of the pancreatic hormones insulin (blue), glucagon (green) and somatostatin (Red) in uniquely shaped islet structures. (B) Pancreatic polypeptide (red) specific antisera fail to stain a specific subset of endocrine cells in the pancreas, while insulin (blue) and glucagon show a normal distribution. (C-D) PYY shows colocalization with most of the insulin immunoreactive cells but not glucagon or somatostatin (E-F). All images are 250x magnification.

been shown to have retained an ancient paralogue of $P d x 1$, which we termed $P d x 2[30,62]$ and accordingly we find transcripts of both genes in our pancreas transcriptome dataset. The basic helix-loop-helix (bHLH) transcription factor NeuroD1 (previously called $\beta 2$ [63]) has roles in pancreas development and islet formation $[64,65]$ and mutations in this gene have been linked to Type 2 Diabetes mellitus and MODY6 [66]. NeuroD1 has also been shown to be important for insulin gene expression [67-69] and the LIM-homeodomain transcription factor Isl1 acts synergistically with NeuroD1 and the bHLH transcription factor E47 to bind to and activate the insulin gene promoter [70-72]. Hepatocyte nuclear factor 1 alpha (Hnf1a) was originally described as a liver-specific transcription actor, responsible for the regulation of a number of genes important for liver function [73-75]. However, it was later found that this protein also has a role in glucose homeostasis via regulation of insulin secretion $[76,77]$ and that mutations in Hnfla were the cause of MODY3 [78-80]. The Nkx6.1 homeodomain transcription factor is a potent transcriptional repressor with a key role in $\beta$-cell differentiation $[81,82]$ and has also been shown to suppress the expression of glucagon to maintain $\beta$-cell identity, as well as being able to regulate glucosesensitive insulin secretion [83]. Our discovery of $P d x 1$ (and Pdx2), NeuroD1 and its partner E47, Isl1, Hnf1a and $N k x 6.1$ transcripts expressed in the catshark pancreas suggests an ancient role for these genes in jawed vertebrate 
pancreas function and hints at early establishment of the insulin gene regulatory network. Additionally, the presence of transcripts encoding NeuroD1, E47, Isl1 and Nkx6.1 in the catshark brain highlights shared ancestry of these tissues in the vertebrate neuroendocrine system. We do not find any transcripts for MafA, which has been shown to be a key regulator of glucose-sensitive insulin secretion in humans and rodents $[58,84,85]$, although other studies have also had difficulty identifying transcripts of this gene and other pancreas transcription factors in nonPCR based experiments [86,87], possibly because of the low level of expression of transcription factors in general [88]. MafB is expressed only in brain and liver.

\section{Transcription factors}

In addition to the transcription factors involved in insulin regulation discussed above, KEGG orthology (KO) analysis [89-91] has identified 13 transcription factors expressed in just the pancreas (including $P d x 1$ and Pdx2, FoxA1 (Hnf3a) and Pancreas-specific transcription factor 1a (Ptf1a)), 14 expressed in pancreas and liver, 33 in pancreas and brain and 51 in all three tissues (Tables 2 and 3).

In a survey of the expression of 790 human DNAbinding transcription factors, Kong et al. [88] identified 80 with expression restricted to the fetal pancreas, 32 restricted to the adult pancreas and 18 shared by both. Of the 32 adult-specific genes, we find evidence that 6 are also expressed in the adult catshark pancreas, although this number increases to 15 if members of the same gene family are considered (the possibility of divergent resolution of gene duplicates following the whole genome duplications [92] in early vertebrate ancestry must be considered). Since transcription factors are known to be expressed at low levels in cells (less than 20 copies per human adult cell [88]) it is likely that our figure is an underestimate and a more comprehensive survey of candidate transcription factor expression in this species is needed.

\section{Signalling}

Our KEGG orthology analysis identified 38 transcripts involved in signal transduction that are expressed only in the catshark pancreas, 11 in both pancreas and liver, 104 in pancreas and brain and 187 in all three tissues (Tables 2 and 3). Among these are representatives of the major vertebrate signalling pathways, including ligands and receptors for Fgf, Wnt, Notch, Vegf, Tgf $\beta$ and Pdgf. Members of all of these pathways have previously been identified in the human pancreas transcriptome [87].

\section{Homeobox gene diversity}

Homeobox genes are a group of transcription factors that encode a 60 amino acid DNA-binding homeodomain and
Table 3 Transcription factors and signaling pathway components unique to the lesser spotted catshark pancreas based on available data

\begin{tabular}{|c|c|}
\hline $\begin{array}{l}\text { Pancreas-specific } \\
\text { transcription factors }\end{array}$ & $\begin{array}{l}\text { Pancreas-specific signaling } \\
\text { components }\end{array}$ \\
\hline Forkhead box protein A1 & 1D-myo-inositol-triphosphate 3-kinase \\
\hline GATA-binding protein 4 & 5-hydroxytryptamine receptor 2 \\
\hline $\begin{array}{l}\text { Histone-lysine } \\
\text { N-methyltransferase MLL1 }\end{array}$ & Adenylate cyclase 2 \\
\hline Homeobox protein hoxB5 & Bone morphogenetic protein 2 \\
\hline Homeobox protein hoxB7 & Bone morphogenetic protein 7 \\
\hline Homeobox protein MOX & Cholecystokinin A receptor \\
\hline $\begin{array}{l}\text { Pancreas and duodenal } \\
\text { homeobox } 1\end{array}$ & Collagen, type I/IIIIIIN/XI/XXIV/XXVII, alpha \\
\hline $\begin{array}{l}\text { Pancreas and duodenal } \\
\text { homeobox } 2\end{array}$ & Collagen, type IV, alpha \\
\hline Krueppel-like factor 5 & Collagen, type VI, alpha \\
\hline $\begin{array}{l}\text { Nuclear receptor subfamily } 0 \\
\text { group B } 1\end{array}$ & Cysteinyl leukotriene receptor 1 \\
\hline $\begin{array}{l}\text { Nuclear receptor subfamily } 0 \\
\text { group B } 1\end{array}$ & Epidermal growth factor receptor \\
\hline $\begin{array}{l}\text { Pancreas-specific transcription } \\
\text { factor 1a }\end{array}$ & Fibroblast growth factor \\
\hline Transcriptional enhancer factor & FMS-like tyrosine kinase 1 \\
\hline \multirow[t]{13}{*}{ Zinc finger protein GLI3 } & Frizzled $9 / 10$ \\
\hline & Glutamine synthetase \\
\hline & Inositol 1,4,5-triphosphate receptor type 1 \\
\hline & Inositol 1,4,5-triphosphate receptor type 2 \\
\hline & Inositol 1,4,5-triphosphate receptor type 3 \\
\hline & Insulin \\
\hline & Integrin alpha 1 \\
\hline & Integrin alpha 2 \\
\hline & Integrin beta 6 \\
\hline & Interleukin 10 receptor beta \\
\hline & Janus kinase 2 \\
\hline & Laminin, alpha 3/5 \\
\hline & Laminin, beta 4 \\
\hline
\end{tabular}

Leucine-rich repeats and death domaincontaining protein

Mitogen-activated protein kinase kinase kinase kinase 4

Nucleoprotein TPR

Protein crumbs

Receptor-interacting serine/threonine-protein kinase 1

Secretory phospholipase A2

Suppressor of cytokine signaling 1

TGF-beta receptor type-2

Transcriptional enhancer factor

Transferrin

Vascular endothelial growth factor C/D

Zinc finger protein GLI3 
that are involved in a wide variety of gene regulatory events in embryonic and adult tissues. A number of homeobox genes are known to be expressed during endodermal regionalisation and pancreas development, including Islet 1 and 2 (Isl1, Isl2), Pancreatic and duodenal homeobox 1 (Pdx1), Nkx6.1, Nkx2.2, Pituitary homeobox 2 (Pitx2), Motor neuron and pancreas homeobox 1 (Mnx1), Onecut homeobox 1 (Onecut/Hnf6) and Paired box genes 4 and 6 (Pax4, Pax6) $[93,94]$. Some older studies have detected a variety of homeobox genes in mammalian pancreas cell lines, including $C d x 4$, Hox1.4 (HoxA4), Chox7 (Gbx1), Hox2.6 (HoxB4), Cdx3 (Cdx2), Cdx1, Hox4.3 (HoxD8), Hox1.11 (HoxA2), Hox4a (HoxD3), Hox1.3 (HoxA5) in the somatostatin-producing rat insulinoma cell line RIN1027-B2 [53] and Isl1, Lmx2, Alx3, HoxA4, HoxA13, Ipf1 (Pdx1), Nkx2.2, Nkx6.1, En2 and $V d x$ in a hamster insulinoma cell line [95]. More recently, microarray and RNA-seq studies have identified a much larger number of homeobox genes expressed in the pancreas and especially the $\beta$-cell, with over 60 different homeobox genes identified by Kutlu et al. [87]. We used the homeodomain sequences of all human homeobox genes from HomeoDB [96,97] and all vertebrate homeobox gene sequences from Pfam [98] as BLAST queries against our catshark transcriptome data and identified 11 different homeobox genes expressed in the pancreas, including five in just pancreas (HoxB5, HoxB7, Mox1, $P d x 1, P d x 2$ ), two in pancreas and liver $(H l x, H h e x)$, three in pancreas and brain $(A r x, Z f h \times 3, Z f h x 4)$ and one in all three tissues (Cut-like 2). These include genes known to be restricted to, or highly expressed in, $\beta$-cells $(P d x 1), \alpha$ cells $(\operatorname{Arx})$ and acinar cell types (Cut-like 2) [86].

\section{Digestion}

In addition to its endocrine roles, the pancreas is also an important exocrine organ, fulfilling key functions in the digestion of proteins, lipids and carbohydrates. In the carnivorous elasmobranchs protein and lipids are the main energy sources [99] and it has been shown that ketone bodies and amino acids are the main oxidative fuel source for muscles and several other tissues, in preference to fatty acids $[24,28,99]$. Carbohydrates are thought to be utilised as oxidative fuels in elasmobranch heart muscle, as well as brain, red muscle and rectal gland $[28,100,101]$. It is therefore perhaps reasonable to assume that proteases and lipases are the most significant digestive enzymes produced by the elasmobranch pancreas and indeed this appears to be the case. Some form of chymotrypsinogen and trypsinogen have long been known to be produced by the elasmobranch pancreas, as has carboxypeptidase $\mathrm{B}$, although these enzymes have not been fully characterised or isolated and sequenced [102-105]. We find transcripts of Elastase $2 a$ and $3 b$, Chymotrypsinogen b1 (Ctrb1), Chymotrypsin-like (Ctrl),
Chymotrypsin-like elastase family, member 1 (Cela1) and Chymotrypsin-like elastase family, member $3 B$ (Cela3b), Trypsin 1, 2 and 3, as well as the digestive carboxypepetidases (A1, A2, B1) and those involved in activation and processing of other proteins, such as carboxypeptidase $B 2, D$ and $E[106,107]$.

Some form of triacylglycerol lipase activity has previously been detected using crude enzyme preparations from the pancreas of skate (Raja (now Amblyraja) radiata) [108] and Leopard shark, Triakis semifasciata [109]. However, we find no evidence of Pancreatic lipase in the catshark pancreas transcriptome and instead find only Pancreatic lipase-related proteins 1 (Pnliprp1) and 2 (Pnliprp2). It is likely therefore that the triacylglycerol lipase activity found previously is a result of the action of Carboxyl ester lipase (CEL or bile salt-stimulated lipase) [110]. We also find colipase, in agreement with earlier studies of a range of cartilaginous fish and other vertebrates [111-113] and Hepatic lipase and Hormone-sensitive lipase. Several lipid transporting apolipoproteins are also expressed by the catshark pancreas, including apolipoproteins $A-I V, E, M$ and $O$. Finally, we have identified transcripts of genes involved in the digestion of carbohydrates (Pancreatic alpha amylase) and nucleic acids (deoxyribonuclease I and various ribonucleases).

\section{Microsatellites}

It has recently been suggested [31] that a high frequency of dinucleotide simple sequence repeats (SSRs, microsatellites) is a general feature of shark genomes. We find 6,843 transcripts containing one or more di-, tri- or tetranucleotide microsatellites of five perfect repeats or more in our catshark data, with 482 of these only in pancreas, 3,083 only in brain and 473 only in liver (Table 4). In accordance with previous suggestions [31] we find dinucleotide repeats to be the most common type of SSR in both coding and non-coding regions of catshark transcripts.

\section{Discussion}

Our analysis of the catshark pancreas transcriptome reveals the presence of genes known to be involved in glucose sensing and regulation of the insulin gene in other jawed vertebrates and illustrates that functional conservation of these aspects is reflected at the molecular-level. We therefore propose that these molecular-level mechanisms are a common feature of jawed vertebrates and that this lends support to the theory that the evolution of blood-glucose sensing and regulatory mechanisms may have facilitated the evolution of the complex glucosedependent brain of jawed vertebrates [7-9]. We further suggest that the early evolution and fixation of these mechanisms has imposed evolutionary constraints on glucose sensing and insulin regulation in jawed vertebrates, 
Table 4 Predicted di-, tri- and tetranucleotide simple sequence repeats (microsatellites) in each catshark tissue or combination or tissues

\begin{tabular}{|c|c|c|c|c|c|c|}
\hline & & ranscript & & & dicted $O$ & \\
\hline & Di- & Tri- & Tetra- & Di- & Tri- & Tetra- \\
\hline Pancreas only & 456 & 23 & 3 & 60 & 6 & 0 \\
\hline & $(6.96 \%)$ & $(0.35 \%)$ & $(0.05 \%)$ & $(0.92 \%)$ & $(0.09 \%)$ & $(0 \%)$ \\
\hline Brain only & 2808 & 268 & 7 & 829 & 147 & 1 \\
\hline & $(13.22 \%)$ & $(1.26 \%)$ & $(0.03 \%)$ & (3.90\%) & $(0.69 \%)$ & $(<0.01 \%)$ \\
\hline Liver only & 446 & 24 & 3 & 168 & 12 & 1 \\
\hline & $(13.03 \%)$ & $(0.70 \%)$ & $(0.09 \%)$ & $(4.90 \%)$ & $(0.35 \%)$ & $(0.03 \%)$ \\
\hline Pancreas + Brain & 481 & 43 & 2 & 72 & 15 & 2 \\
\hline & $(12.50 \%)$ & $(1.12 \%)$ & $(0.05 \%)$ & $(1.87 \%)$ & $(0.39 \%)$ & $(0.05 \%)$ \\
\hline Pancreas + Liver & 105 & 5 & 1 & 44 & 3 & 1 \\
\hline & $(11.36 \%)$ & $(0.54 \%)$ & $(0.11 \%)$ & $(4.76 \%)$ & $(0.32 \%)$ & $(0.11 \%)$ \\
\hline Brain + Liver & 702 & 61 & 3 & 106 & 21 & 0 \\
\hline & $(28.28 \%)$ & $(2.46 \%)$ & $(0.12 \%)$ & (11.47\%) & $(2.27 \%)$ & $(0 \%)$ \\
\hline Pancreas + Liver + Brain & 1240 & 158 & 4 & 308 & 108 & 2 \\
\hline & (19.60\%) & $(2.50)$ & $(0.06 \%)$ & $(4.87 \%)$ & $(1.71 \%)$ & $(0.03 \%)$ \\
\hline
\end{tabular}

Results are shown for both full transcripts and predicted open reading frames (ORFs) and in both cases dinucleotide repeats are the most common.

including in cartilaginous fish, even in the face of their ability to tolerate extended periods of hypoglycaemia and likely relaxed requirements for these processes.

We have identified a striking variation in the number of assembled contigs with matches in the RefSeq database (Table 2) and suggest that this is likely to be the result of several different factors, including stringency of cutoffs in BLAST searches and variation in the representation of various tissue types in the RefSeq database itself. It will be interesting to see what impact the ability to map reads to the lesser spotted catshark genome sequence (currently underway at Genoscope www.genoscope.cns.fr) will have on similar analyses in the future.

We find that the catshark pancreas produces at least eight peptide hormones (insulin; glucagon; somatostatin; peptide YY; gastrin-releasing peptide, neuromedin U, encephalin and vasoactive intestinal polypeptide, Table 5) and expresses a wide variety of genes involved in digestion, especially the digestion of proteins and lipids. The catshark pancreas therefore clearly has the features of a distinct pancreatic gland with both endocrine and exocrine functions and as such will be of great use in reconstructing the characteristics of the earliest jawed vertebrate pancreas. The similarity in gene expression between the catshark and other jawed vertebrates with respect to hormones, digestive enzymes, transcription factors and signaling pathways again provides support to the theory that there was a single, early origin of the pancreas at the base of the jawed vertebrate radiation. The overlap in peptides produced by the catshark pancreas and brain (Table 5) is a reflection of
Table 5 Peptide diversity of the catshark pancreas, brain and liver

\begin{tabular}{|c|c|c|c|c|}
\hline Peptide & $\begin{array}{c}\text { Pancreas } \\
\text { IHC }\end{array}$ & $\begin{array}{c}\text { Pancreas } \\
\text { transcriptome }\end{array}$ & $\begin{array}{c}\text { Brain } \\
\text { transcriptome }\end{array}$ & $\begin{array}{c}\text { Liver } \\
\text { transcriptome }\end{array}$ \\
\hline Insulin & + & + & - & - \\
\hline Glucagon & + & + & - & - \\
\hline Somatostatin & + & + & + & - \\
\hline $\begin{array}{l}\text { Pancreatic } \\
\text { polypeptide }\end{array}$ & + & - & - & - \\
\hline Peptide YY & + & + & + & - \\
\hline $\begin{array}{l}\text { Gastrin- } \\
\text { releasing } \\
\text { peptide }\end{array}$ & + & + & + & - \\
\hline Neuromedin U & + & + & + & + \\
\hline Enkephalin & + & + & + & - \\
\hline Cholecystokinin & + & - & + & - \\
\hline Gastrin & + & - & - & - \\
\hline $\begin{array}{l}\text { Vasoactive } \\
\text { intestinal } \\
\text { polypeptide }\end{array}$ & + & + & + & - \\
\hline $\begin{array}{l}\text { Gastric } \\
\text { inhibitory } \\
\text { polypeptide }\end{array}$ & + & - & - & - \\
\hline Secretin & + & - & - & - \\
\hline
\end{tabular}

Our comprehensive transcriptomic survey of the lesser spotted catshark pancreas highlights the disparity in the estimation of peptide diversity in early vertebrates as previously suggested by immunohistochemical (IHC) studies and highlights the similarity of pancreas and brain peptide complements. 
the shared ancestry of these tissues within the vertebrate neuroendocrine system [114].

Based on its co-localisation with insulin-, glucagon-, somatostatin- and PP-cells during mouse development, it has previously been suggested that a PYY + cell may constitute a common progenitor of the major islet cell types [115], see also [116,117]. Recent lineage tracing experiments have demonstrated that PYY + cells give rise to islet $\partial$ and PP cells and approximately $40 \%$ of pancreatic $\alpha$ and at least some $\beta$ cells arose from peptide YY+ cells [118]. Most $\beta$ cells and the majority of $\alpha$ cells are therefore not descendants of the peptide $\mathrm{YY}+$ /glucagon +/insulin + cells that first appear during early pancreas ontogeny. The co-localisation of PYY with insulin in the adult shark pancreas illustrates the diversity of mechanisms that exist in vertebrate pancreas development and function and demonstrates the utility of "non-model" species to study these processes. The catshark PYY+ cells will therefore provide important insights into the evolution of the vertebrate pancreas, and especially progenitors of $\alpha, \beta, \delta$ and $\gamma$-cells.

Our experiments make clear that much of the previous work on the presence or absence of peptides in some vertebrate lineages may be suspect, with many falsepositive signals resulting from cross-reacting antisera. Previous schemes of pancreas evolution based on these and similar data, which posited the restriction of various hormones to the alimentary canal (similar to the situation in protochordates such as amphioxus), the accumulation of these into a two-or three peptide islet organ in jawless fish and finally the "classic four-hormone islet tissue" of cartilaginous fish and other vertebrates [2] are therefore incorrect. In fact, it appears that the three hormone (glucagon, insulin, somatostatin) islet organ was established early in vertebrate evolution and remains today in the adult (but not larval) lamprey, cartilaginous fish and actinopterygian (ray-finned) fish, and that it is only in the sarcopterygian (lobe-finned fish) lineage that a four hormone (the above, plus PP [34,36]) pancreas was formed.

Our analysis of homeobox gene expression reveals a surprising level of variation between the genes known to be expressed in the catshark pancreas, human islets [87] and rat [53] and hamster [95] cell lines. It therefore seems likely that this particular class of transcription factors is extremely variable with respect to their spatial or temporal expression pattern in the pancreas (or more likely both) and this is perhaps not too surprising given the variety of roles carried out by the pancreas in response to feeding, digestion and the regulation of blood glucose. As expected we have identified transcripts of both $P d x 1$ and $P d x 2$ in the catshark pancreas, although we do not find any evidence for the presence of additional duplicates of other genes encoding proteins known to interact with PDX1 in other species. It therefore seems unlikely that the maintenance of paralogous $P d x 2$ genes in some jawed vertebrate lineages [30,62] reflects a wider conservation of duplicated gene regulatory networks produced as a result of whole genome duplication events early in vertebrate evolution. Comparison of the amino acid sequences of PDX1 and PDX2 across vertebrates shows conservation of the Pbx-interacting motif, DNA-binding domain and nuclear localisation signal but not of known transactivation domains and the PCIF1-interaction domain [119-121] (Figure 9). The functions of the $P d x 2$ gene and the reasons for its retention in some species and independent loss in others (ray-finned fish and tetrapods [30] and possibly hagfish depending on the timing of the duplication of the $P d x 1 / 2$ gene $[122,123])$ remain unknown.

With the availability of whole genome sequence information for a greater number of taxa and improved coverage of vertebrate pancreas transcriptomes a larger amount of data than ever before is now becoming available. These data, together with an appreciation that early vertebrate evolution was characterised by extensive genetic, developmental and morphological innovation facilitated by multiple whole genome duplications [124,125] will better enable us to reconstruct pancreas evolution. As an example, we propose that the creation of the paralogous NPY and PYY during these duplications [34] facilitated the separation of the neuronal and gastroenteropancreatic (GEP) endocrine systems. We further suggest that the availability of additional copies of developmentally-important genes produced during the same duplication events [125] enabled the remodelling of the developing gut and the formation of a distinct pancreas with both endocrine and exocrine functions.

\section{Conclusions}

We have generated a multi-tissue transcriptomic resource for an up and coming model organism, the lesser spotted catshark, Scyliorhinus canicula. Somewhat surprisingly we find few transcripts in common between the liver and pancreas, despite their relatively similar roles and shared developmental history as endodermal neighbors. The higher number of transcripts in common between brain and pancreas may provide evidence in support of the co-opting of neuronal programs by at least some pancreatic cells during vertebrate evolution $[114,126]$, although further comparative analyses are needed in this area. The similarity between the catshark pancreas transcriptome and those of various mammals with respect to insulin regulation, transcriptional and signaling machinery and peptide hormones and their receptors supports the single, early origin of a distinct pancreatic gland in jawed vertebrates, although it seems likely that the peptide diversity of the early vertebrate pancreas 


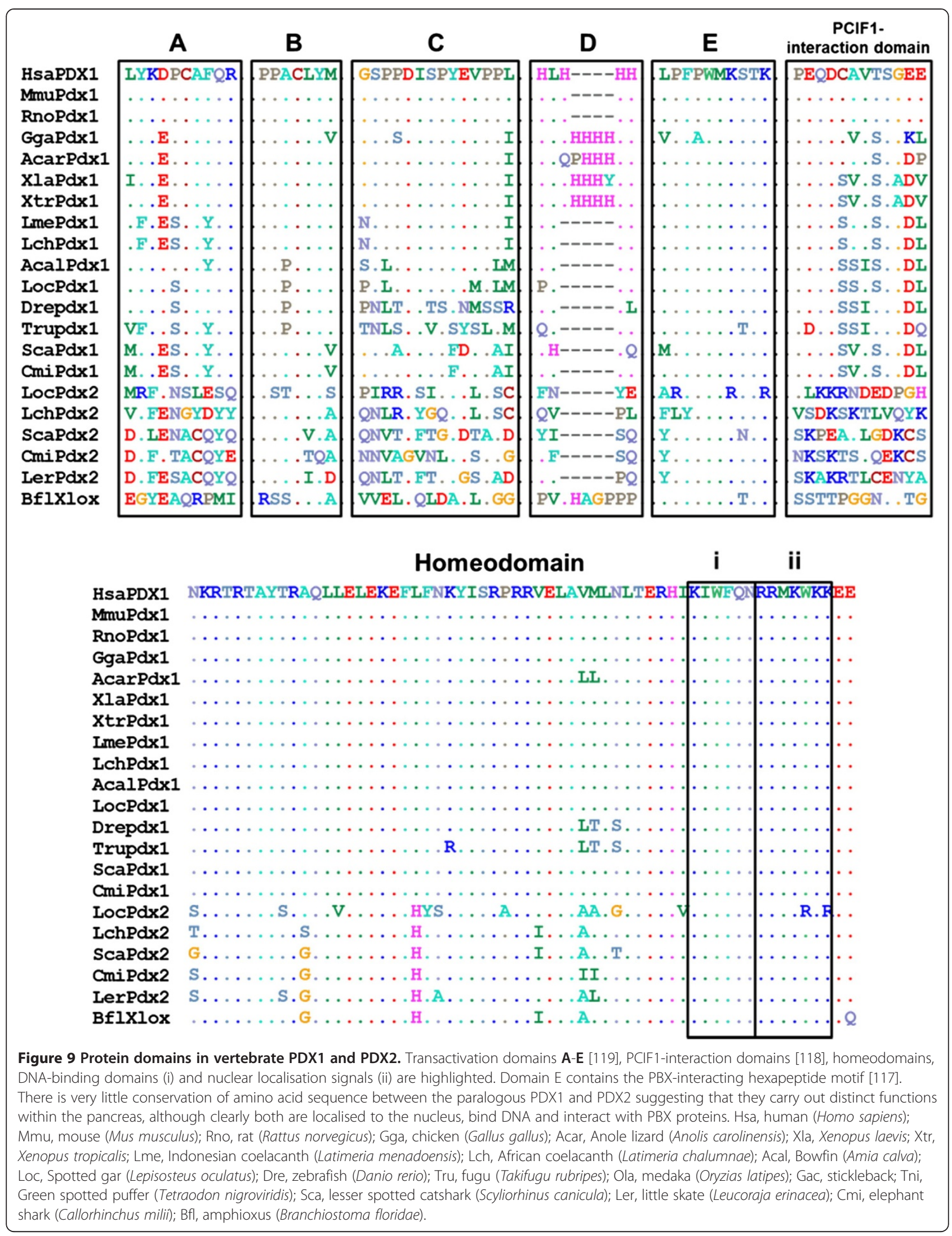


may have been overestimated by older, immunohistochemical studies. The cartilaginous fish have a three peptide (insulin, glucagon and somatostatin) pancreas and the four peptide system seen in lobe-finned fish (at least coelacanths [127] plus tetrapods) is a later evolutionary innovation (Figure 10). The retention of the $P d x 2$ gene in cartilaginous fish does not apparently reflect a wider retention of duplicated members of pancreas gene regulatory networks and the possible function(s) of this gene remains enigmatic. Our data, together with available or in progress transcriptomic and genomic resources for this and other chondrichthyan species will greatly facilitate comparative studies of elasmobranch, chondrichthyan and vertebrate evolution, particularly with reference to energy metabolism and the maintenance of stable blood glucose levels.

\section{Methods}

\section{RNA-Seq and sequence analysis}

Experimental methods involving animals followed institutional and national guidelines and were approved by the Bangor University Ethical Review Committee. Total RNA was extracted from freshly-dissected pancreas, liver and brain of two adult male and female catsharks approximately 24 hours post feeding. Pancreas samples were sequenced with using $2 \times 250$ bp paired-end reads on the Illumina MiSeq platform at the Centre for Genomic Research (CGR) at the University of Liverpool. Brain and liver samples were sequenced using $2 \times 150 \mathrm{bp}$ paired-end reads on the Illumina HiSeq 2000 platform at the Institute of Biological, Environmental \& Rural Sciences (IBERS) at
Aberystwyth University. Sequencing reads from the three tissues were assembled into a global tissue assembly using Trinity [128] with the jellyfish K-mer counting method. Tissue distribution of transcripts was assessed by mapping sequencing reads from each tissue to this global assembly, with an FPKM (fragments per kilobase per million mapped reads) value of $>1$ taken as confirmation of expression. Transcript annotation and assignment of gene ontology (GO) terms was performed using BLAST2GO $[129,130]$ with a cutoff expect ('e') value of 1e-3; the KEGG Automatic Annotation Server (KAAS [90]) and by local BLAST using BLAST + v2.2.27 [131]. The identity of transcripts discussed in the text was verified by reciprocal BLAST against the GenBank sequence database and/or phylogenetic analysis where necessary.

Catshark RNA-Seq reads have been deposited in the NCBI database under the BioProject ID PRJNA255185 and the full Trinity assembly and pools of tissue-specific contigs have been deposited in the Dryad Digital Repository (doi: http://dx.doi.org/10.5061/dryad.s1f22.

\section{Immunohistochemistry}

Male catsharks were euthanized according to a Schedule 1 method and the pancreas removed and fixed in $4 \%$ paraformaldehyde/PBS overnight at $4^{\circ} \mathrm{C}$. The fixed pancreas was then rinsed several times in PBS, dehydrated through a graded ethanol series and stored in $100 \%$ ethanol. $5 \mu \mathrm{m}$ sections of paraffin embedded catshark pancreas were cut and mounted on glass slides. Slides were microwave treated in Tris-EGTA (TEG) buffer ph9.0 and allowed to cool for 30 mins. Slides were rinsed in

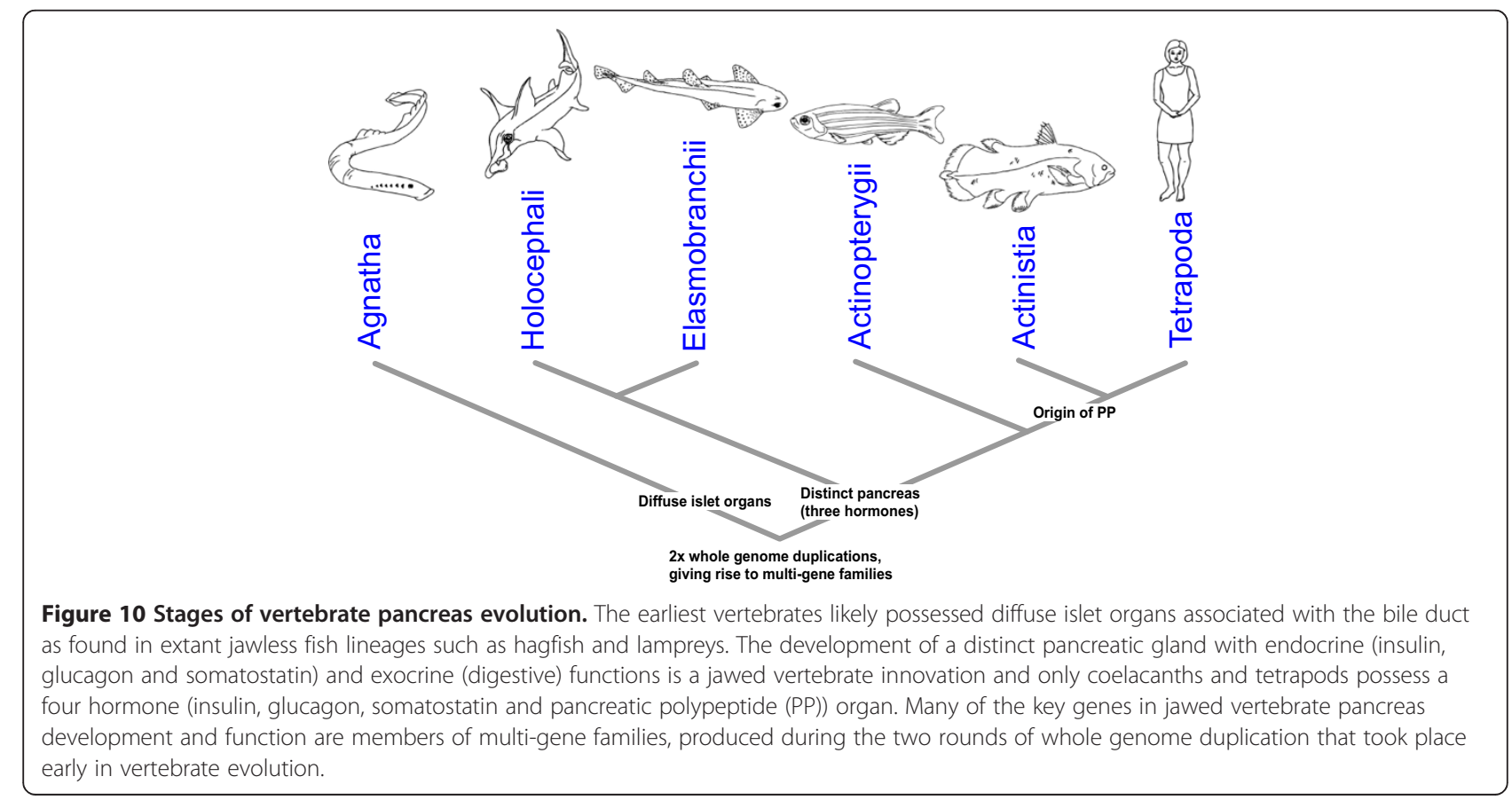


PBS and blocked in normal donkey serum and TNB buffer (Perkin Elmer) for 30mins. Primary antisera were added over night at room temperature and the next day the slides were rinsed $3 \times 5$ min each in PBS and specific cross absorbed donkey anti- mouse, rabbit, or guinea pig secondary antisera (Jackson Immunoresearch) were added for 30mins. The slides were rinsed in PBS and mounted. Details of antisera are given in Additional file 2: Table S1. All pictures were taken on a Zeiss Meta510 confocal microscope.

\section{Antibody absorption}

In order to test their specificity against the Pancreatic polypeptide family, the antisera were incubated overnight at $4^{\circ} \mathrm{C}$ with $10 \mu \mathrm{g}$ of either pancreatic polypeptide (Sigma), Neuropeptide Y (Bachem) or peptide YY (in-house synthesis) or no peptide. The next day the antisera were added to the slides and the staining was performed as above. The staining intensity was compared to the no peptide control and given a rating of $1-3(+,++,+++)$. The results are shown in Additional file 2: Table S2.

\section{Additional files}

Additional file 1: Full gene ontology (GO) term comparative enrichment results.

Additional file 2: Details of antibodies and absorption assays used in immunohistochemistry experiments.

\section{Competing interests}

The authors declare that they have no competing interests.

\section{Authors' contributions}

JFM devised the study and drafted the manuscript; JFM, ADH MJH and MTS carried out RNA-Seq experiments and data analysis, RSH carried out immunohistochemical experiments. All authors read and approved the final manuscript.

\section{Acknowledgements \\ This research was supported by a Diabetes UK Small Grant to JFM and donations by the Llandudno and District Diabetes Group. We thank Ashley Tweedale and Gavan Cooke for assistance with collection and maintenance of catsharks and Charity MK McGrae for assistance with immunohistochemistry and imaging. We would like to thank the anonymous reviewers for their helpful comments and suggestions. The authors also acknowledge the artistic skills of Tatiana Solovieva for help with the figures. JFM, MJH and MTS are supported by the Biosciences, Environment and Agriculture Alliance (BEAA) between Bangor University and Aberystwyth University and ADH is funded by a Bangor University $125^{\text {th }}$ Anniversary Studentship.}

\section{Author details}

${ }^{1}$ School of Biological Sciences, Bangor University, Brambell Building, Deiniol Road, Bangor, Gwynedd LL57 2UW, United Kingdom. '2Institute of Biological, Environmental \& Rural Sciences, Aberystwyth University, Penglais, Aberystwyth, Ceredigion SY23 3DA, United Kingdom. ${ }^{3}$ Histology and Imaging Department, Novo Nordisk A/S, Novo Nordisk Park, DK2760 Måløv, Denmark.

Received: 16 June 2014 Accepted: 27 November 2014

Published: 6 December 2014

\section{References}

1. Falkmer S: Origin of the parenchymal cells of the endocrine pancreas: some phylogenetic and ontogenetic aspects. Front Gastrointest Res 1995, 23:2-29.

2. Youson $\mathrm{JH}, \mathrm{Al}-\mathrm{Mah}$ rouki AA: Ontogenetic and phylogenetic development of the endocrine pancreas (islet organ) in fishes. Gen Comp Endocrinol 1999, 116:303-335.

3. Heller RS: The comparative anatomy of islets. Islets 2010, 654:21-37.

4. Epple A, Brinn JE: Pancreatic Islets. In Vertebrate Endocrinology: Fundamentals and Biomedical Implications. New York: Academic; 1986:279-317.

5. Shimeld SM, Holland PWH: Vertebrate innovations. Proc Natl Acad Sci U S A 2000, 97:4449-4452.

6. Khaner O: Evolutionary innovations of the vertebrates. Integr Zool 2007, 2:60-67.

7. Ainali C, Simon M, Freilich S, Espinosa O, Hazelwood L, Tsoka S, Ouzounis CA, Hancock JM: Protein coalitions in a core mammalian biochemical network linked by rapidly evolving proteins. BMC Evol Biol 2011, 11:142.

8. Rashidi A, Kirkwood TBL, Shanley DP: Metabolic evolution suggests an explanation for the weakness of antioxidant defences in beta-cells. Mech Ageing Dev 2009, 130:216-221.

9. Madsen OD: Pancreas phylogeny and ontogeny in relation to a "pancreatic stem cell". C R Biol 2007, 330:534-537.

10. Wu Q, Brown MR: Signaling and function of insulin-like peptides in insects. Annu Rev Entomol 2006, 51:1-24.

11. Anderson WG, Ali MF, Einarsdottir IE, Schaffer L, Hazon N, Conlon JM: Purification, characterization, and biological activity of insulins from the spotted dogfish, Scyliorhinus canicula, and the hammerhead shark, Sphyrna lewini. Gen Comp Endocrinol 2002, 126:113-122.

12. Conlon JM, Hazon N, Thim L: Primary structures of peptides derived from proglucagon isolated from the pancreas of the elasmobranch fish, Scyliorhinus canicula. Peptides 1994, 15:163-167.

13. Conlon JM, Balasubramaniam A, Hazon N: Structural characterization and biological activity of a neuropeptide $\mathrm{Y}$-related peptide from the dogfish, Scyliorhinus canicula. Endocrinology 1991, 128:2273-2279.

14. Conlon JM, Bjenning C, Hazon N: Structural characterization of neuropeptide $Y$ from the brain of the dogfish, Scyliorhinus canicula. Peptides 1992, 13:493-497.

15. Conlon JM, Dafgard E, Falkmer S, Thim L: A glucagon-like peptide, structurally related to mammalian oxyntomodulin, from the pancreas of a holocephalan fish, Hydrolagus colliei. Biochem J 1987, 245:851-855.

16. El-Salhy M: Immunocytochemical investigation of the gastro-enteropancreatic (GEP) neurohormonal peptides in the pancreas and gastrointestinal tract of the dogfish Squalus acanthias. Histochem Cell Biol 1984, 80:193-205.

17. Kobayashi K, Syed Ali S: Cell types of the endocrine pancreas in the shark Scyliorhinus stellaris as revealed by correlative light and electron microscopy. Cell Tissue Res 1981, 215:475-490.

18. Sekine $Y$, Yui R: Immunohistochemical study of the pancreatic endocrine cells of the ray, Dasyatis akajei. Arch Histol Jpn 1981, 44:95-101.

19. Diamare V: Vergleichende anatomisch-physiologische Studien fiber den Pankreasdiabetes. III Mitt. Zentralblatt für Physiologie 1908, 21:863-869.

20. Diamare V: Weitere Beobachtungen über den Experimentaldiabetes nach Pankreasextirpation bei Selachier. Zentralblatt für Physiologie 1906 20:617-620.

21. de Roos R, de Roos CC, Werner CS, Werner H: Plasma levels of glucose, alanine, lactate, and [beta]-hydroxybutyrate in the unfed spiny dogfish shark (Squalus acanthias) after surgery and following mammalian insulin infusion. Gen Comp Endocrinol 1985, 58:28-43.

22. de Roos R, de Roos CC: Severe insulin-induced hypoglycemia in the spiny dogfish shark (Squalus acanthias). Gen Comp Endocrinol 1979, 37:186-191.

23. Patent GJ: The chondrichthyean endocrine pancreas: What are its functions? Am Zool 1973, 13:639-651.

24. Zammit VA, Newsholme EA: Activities of enzymes of fat and ketone-body metabolism and effects of starvation on blood concentrations of glucose and fat fuels in teleost and elasmobranch fish. Biochem J 1979, 184:313-322.

25. Walsh PJ, Kajimura M, Mommsen TP, Wood CM: Metabolic organization and effects of feeding on enzyme activities of the dogfish shark (Squalus acanthias) rectal gland. J Exp Biol 2006, 209:2929-2938.

26. Polakof S, Mommsen TP, Soengas JL: Glucosensing and glucose homeostasis: from fish to mammals. Comp Biochem Physiol B Biochem Mol Biol 2011, 160:123-149. 
27. Patent GJ: Comparison of some hormonal effects on carbohydrate metabolism in an elasmobranch (Squalus acanthias) and a holocephalan (Hydrolagus colliei). Gen Comp Endocrinol 1970, 14:215-242.

28. Speers-Roesch B, Treberg JR: The unusual energy metabolism of elasmobranch fishes. Comp Biochem Physiol A Mol Integr Physiol 2010, 155:417-434.

29. Coolen M, Menuet A, Chassoux D, Compagnucci C, Henry S, Lévèque L, Da Silva C, Gavory F, Samain S, Wincker P: The dogfish Scyliorhinus canicula, a reference in jawed vertebrates. CSH Protoc 2008, doi:10.1101/pdb.emo111.

30. Mulley JF, Holland PWH: Parallel retention of $P d x 2$ genes in cartilaginous fish and coelacanths. Mol Biol Evol 2010, 27:2386-2391.

31. Richards V, Suzuki H, Stanhope M, Shivji M: Characterization of the heart transcriptome of the white shark (Carcharodon carcharias). BMC Genomics 2013, 14:697.

32. Conlon JM, Reinecke M, Thorndyke MC, Falkmer S: Insulin and other islet hormones (somatostatin, glucagon and PP) in the neuroendocrine system of some lower vertebrates and that of invertebrates: a minireview. Horm Metab Res 1988, 20:406-410.

33. Quan FB, Kenigfest NB, Mazan S, Tostivint H: Molecular cloning of the CDNAs encoding three somatostatin variants in the dogfish (Scylorhinus canicula). Gen Comp Endocrinol 2013, 180:1-6.

34. Larsson TA, Tay BH, Sundstrom G, Fredriksson R, Brenner S, Larhammar D, Venkatesh B: Neuropeptide Y-family peptides and receptors in the elephant shark, Callorhinchus milii confirm gene duplications before the gnathostome radiation. Genomics 2009, 93:254-260.

35. Falkmer S: Phylogeny and ontogeny of the neuroendocrine cells of the gastrointestinal tract. Endocrinol Metab Clin North Am 1993, 22:731-752.

36. Larhammar D: Evolution of neuropeptide Y, peptide YY and pancreatic polypeptide. Regul Pept 1996, 62:1-11.

37. Sundstrom G, Larsson TA, Brenner S, Venkatesh B, Larhammar D: Evolution of the neuropeptide $Y$ family: new genes by chromosome duplications in early vertebrates and in teleost fishes. Gen Comp Endocrinol 2008, 155:705-716.

38. Conlon JM, Bjenning C, Moon TW, Youson JH, Thim L: Neuropeptide Y-related peptides from the pancreas of a teleostean (eel), holostean (bowfin) and elasmobranch (skate) fish. Peptides 1991, 12:221-226.

39. El-Salhy M, Grimelius L, Emson PC, Falkmer S: Polypeptide YY-and neuropeptide Y-immunoreactive cells and nerves in the endocrine and exocrine pancreas of some vertebrates: an onto-and phylogenetic study. Histochem J 1987, 19:111-117.

40. Reinecke M, Weimar E, Maake C, Drakenberg K, Falkmer S, Sara VR: IGF-2like peptides are present in insulin cells of the elasmobranchian endocrine pancreas: an immunohistochemical and chromatographic study. Histochem Cell Biol 1994, 102:365-371.

41. Moghimzadeh E, Ekman R, Hakanson R, Yanaihara N, Sundler F: Neuronal gastrin-releasing peptide in the mammalian gut and pancreas. Neuroscience 1983, 10:553-563.

42. Cornelio DB, Roesler R, Schwartsmann G: Gastrin-releasing peptide receptor as a molecular target in experimental anticancer therapy. Ann Oncol 2007, 18:1457-1466.

43. Raddatz R, Wilson AE, Artymyshyn R, Bonini JA, Borowsky B, Boteju LW, Zhou S, Kouranova EV, Nagorny R, Guevarra MS: Identification and characterization of two neuromedin $U$ receptors differentially expressed in peripheral tissues and the central nervous system. J Biol Chem 2000, 275:32452-32459.

44. Frederickson RC: Enkephalin pentapeptides-a review of current evidence for a physiological role in vertebrate neurotransmission. Life Sci 1977, 21:23-42.

45. Yoshimasa T, Nakao K, Ohtsuki H, Li S, Imura H: Methionine-enkephalin and leucine-enkephalin in human sympathoadrenal system and pheochromocytoma. J Clin Invest 1982, 69:643-650.

46. Leighton B, Atkinson A, Coghlan MP: Small molecule glucokinase activators as novel anti-diabetic agents. Biochem Soc Trans 2005, 33:371-374.

47. Fajans SS, Bell Gl, Polonsky KS: Molecular mechanisms and clinical pathophysiology of maturity-onset diabetes of the young. $N$ Engl J Med 2001, 345:971-980.

48. Vionnet N, Stoffel M, Takeda J, Yasuda K, Bell Gl, Zouali H, Lesage S, Velho G, Iris F, Passa PH: Nonsense mutation in the glucokinase gene causes early-onset non-insulin-dependent diabetes mellitus. Nature 1992, 356:721-722.
49. De Vos A, Heimberg H, Quartier E, Huypens P, Bouwens L, Pipeleers D, Schuit F: Human and rat beta cells differ in glucose transporter but not in glucokinase gene expression. J Clin Invest 1995, 96:2489-2495.

50. Ferrer J, Benito C, Gomis R: Pancreatic islet GLUT2 glucose transporter mRNA and protein expression in humans with and without NIDDM. Diabetes 1995, 44:1369-1374.

51. Richardson CC, Hussain K, Jones PM, Persaud S, Lobner K, Boehm A, Clark A, Christie MR: Low levels of glucose transporters and channels in human pancreatic beta cells early in development. Diabetologia 2007, 50:1000-1005.

52. Leonard J, Peers B, Johnson T, Ferreri K, Lee S, Montminy MR: Characterization of somatostatin transactivating factor-1, a novel homeobox factor that stimulates somatostatin expression in pancreatic islet cells. Mol Endocrinol 1993, 7:1275-1283.

53. Miller CP, McGehee RE Jr, Habener JF: IDX-1: a new homeodomain transcription factor expressed in rat pancreatic islets and duodenum that transactivates the somatostatin gene. EMBO J 1994, 13:1145-1156.

54. Ohlsson H, Karlsson K, Edlund T: IPF1, a homeodomain-containing transactivator of the insulin gene. EMBO J 1993, 12:4251-4259.

55. Boam DS, Docherty K: A tissue-specific nuclear factor binds to multiple sites in the human insulin-gene enhancer. Biochem J 1989, 264:233-239.

56. Marshak S, Benshushan E, Shoshkes M, Havin L, Cerasi E, Melloul D: Functional conservation of regulatory elements in the pdx-1 gene: PDX-1 and hepatocyte nuclear factor 3 beta transcription factors mediate beta-cell-specific expression. Mol Cell Biol 2000, 20:7583-7590.

57. Ohneda K, Mirmira RG, Wang J, Johnson JD, German MS: The homeodomain of PDX-1 mediates multiple protein-protein interactions in the formation of a transcriptional activation complex on the insulin promoter. Mol Cell Biol 2000, 20:900-911.

58. Docherty HM, Hay CW, Ferguson LA, Barrow J, Durward E, Docherty K: Relative contribution of PDX-1, MafA and E47/ $\beta 2$ to the regulation of the human insulin promoter. Biochem J 2005, 389:813-820.

59. Stoffers DA, Ferrer J, Clarke WL, Habener JF: Early-onset type-Il diabetes mellitus (MODY4) linked to IPF1. Nat Genet 1997, 17:138-141.

60. Stoffers DA, Zinkin NT, Stanojevic V, Clarke WL, Habener JF: Pancreatic agenesis attributable to a single nucleotide deletion in the human IPF1 gene coding sequence. Nat Genet 1997, 15:106-110.

61. Schwitzgebel VM, Mamin A, Brun T, Ritz-Laser B, Zaiko M, Maret A, Jornayvaz FR, Theintz GE, Michielin O, Melloul D: Agenesis of human pancreas due to decreased half-life of insulin promoter factor 1. J Clin Endocrinol Metab 2003, 88:4398-4406.

62. Mulley JF, Holland PWH: Genomic organisation of the seven ParaHox genes of coelacanths. J Exp Zool B Mol Dev Evol 2014, 322:352-358.

63. Poulin G, Turgeon B, Drouin J: NeuroD1/beta2 contributes to cell-specific transcription of the proopiomelanocortin gene. Mol Cell Biol 1997, 17:6673-6682.

64. Chao CS, Loomis ZL, Lee JE, Sussel L: Genetic identification of a novel NeuroD1 function in the early differentiation of islet $a, P P$ and $\varepsilon$ cells. Dev Biol 2007, 312:523-532.

65. Chae $\mathrm{JH}$, Stein $\mathrm{GH}$, Lee JE: NeuroD: the predicted and the surprising. Mol Cells 2004, 18:271-288.

66. Malecki MT, Jhala US, Antonellis A, Fields L, Doria A, Orban T, Saad M, Warram JH, Montminy M, Krolewski AS: Mutations in NEUROD1 are associated with the development of type 2 diabetes mellitus. Nat Genet 1999, 23:323-328.

67. Naya FJ, Stellrecht CM, Tsai MJ: Tissue-specific regulation of the insulin gene by a novel basic helix-loop-helix transcription factor. Genes Dev 1995, 9:1009-1019.

68. Naya FJ, Huang HP, Qiu Y, Mutoh H, DeMayo FJ, Leiter AB, Tsai MJ: Diabetes, defective pancreatic morphogenesis, and abnormal enteroendocrine differentiation in BETA2/neuroD-deficient mice. Genes Dev 1997, 11:2323-2334.

69. Qiu Y, Guo M, Huang $S$, Stein R: Insulin gene transcription is mediated by interactions between the p300 coactivator and PDX-1, BETA2, and E47. Mol Cell Biol 2002, 22:412-420.

70. Zhang H, Wang WP, Guo T, Yang JC, Chen P, Ma KT, Guan YF, Zhou CY: The LIM-homeodomain protein ISL1 activates insulin gene promoter directly through synergy with BETA2. J Mol Biol 2009, 392:566-577.

71. Peng SY, Wang WP, Meng J, Li T, Zhang H, Li Y, Chen P, Ma KT, Zhou CY: ISL1 physically interacts with BETA2 to promote insulin gene transcriptional synergy in non-beta cells. Biochim Biophys Acta 2005, 1731:154-159. 
72. Glick E, Leshkowitz D, Walker MD: Transcription factor BETA2 acts cooperatively with E2A and PDX1 to activate the insulin gene promoter. J Biol Chem 2000, 275:2199-2204.

73. Courtois G, Morgan JG, Campbell LA, Fourel G, Crabtree GR: Interaction of a liver-specific nuclear factor with the fibrinogen and alpha 1-antitrypsin promoters. Science 1987, 238:688-692.

74. Brooks AR, Levy-Wilson B: Hepatocyte nuclear factor 1 and C/EBP are essential for the activity of the human apolipoprotein $B$ gene second-intron enhancer. Mol Cell Biol 1992, 12:1134-1148.

75. Maire $P$, Wuarin J, Schibler U: The role of cis-acting promoter elements in tissue-specific albumin gene expression. Science 1989, 244:343-346.

76. Emens LA, Landers DW, Moss LG: Hepatocyte nuclear factor 1 alpha is expressed in a hamster insulinoma line and transactivates the rat insulin I gene. Proc Natl Acad Sci U S A 1992, 89:7300-7304.

77. Pontoglio M, Sreenan S, Roe M, Pugh W, Ostrega D, Doyen A, Pick AJ, Baldwin A, Velho G, Froguel P: Defective insulin secretion in hepatocyte nuclear factor 1 alpha-deficient mice. J Clin Invest 1998, 101:2215-2221.

78. Yamagata K, Oda N, Kaisaki PJ, Menzel S, Furuta H, Vaxillaire M, Southam L, Cox RD, Lathrop GM, Boriraj W: Mutations in the hepatocyte nuclear factor-1 alpha gene in maturity-onset diabetes of the young (MODY3). Nature 1996, 384:455-458.

79. Vaxillaire M, Rouard M, Yamagata K, Oda N, Kaisaki PJ, Boriraj W, Chevre JC, Boccio V, Cox RD, Lathrop GM: Identification of nine novel mutations in the hepatocyte nuclear factor 1 alpha aene associated with maturity-onset diabetes of the young (MODY3). Hum Mol Genet 1997, 6:583-586.

80. Bjorkhaug L, Sagen JV, Thorsby P, Sovik O, Molven A, Njolstad PR: Hepatocyte nuclear factor-1a gene mutations and diabetes in Norway. J Clin Endocrinol Metab 2003, 88:920-931.

81. Iype T, Taylor DG, Ziesmann SM, Garmey JC, Watada H, Mirmira RG: The transcriptional repressor Nkx6. 1 also functions as a deoxyribonucleic acid context-dependent transcriptional activator during pancreatic $\beta$-cell differentiation: evidence for feedback activation of the nkx6.1 gene by Nkx6. 1. Mol Endocrinol 2004, 18:1363-1375.

82. Sander M, Sussel L, Conners J, Scheel D, Kalamaras J, Cruz FD, Schwitzgebel V, Hayes-Jordan A, German M: Homeobox gene Nkx6. 1 lies downstream of Nkx2. 2 in the major pathway of beta-cell formation in the pancreas. Development 2000, 127:5533-5540.

83. Schisler JC, Jensen PB, Taylor DG, Becker TC, Knop FK, Takekawa S, German M, Weir GC, Lu D, Mirmira RG: The Nkx6. 1 homeodomain transcription factor suppresses glucagon expression and regulates glucose-stimulated insulin secretion in islet beta cells. Proc Natl Acad Sci U S A 2005, 102:7297-7302.

84. Aramata S, Han SI, Kataoka K: Roles and regulation of transcription factor MafA in islet beta-cells. Endocr J 2007, 54:659-666.

85. Zhang C, Moriguchi T, Kajihara M, Esaki R, Harada A, Shimohata H, Oishi H, Hamada M, Morito N, Hasegawa K: MafA is a key regulator of glucose-stimulated insulin secretion. Mol Cell Biol 2005, 25:4969-4976.

86. Dorrell C, Schug J, Lin CF, Canaday PS, Fox AJ, Smirnova O, Bonnah R, Streeter PR, Stoeckert CJ, Kaestner KH: Transcriptomes of the major human pancreatic cell types. Diabetologia 2011, 54:2832-2344.

87. Kutlu B, Burdick D, Baxter D, Rasschaert J, Flamez D, Eizirik D, Welsh N, Goodman N, Hood L: Detailed transcriptome atlas of the pancreatic beta cell. BMC Med Genomics 2009, 2:3

88. Kong YM, MacDonald RJ, Wen X, Yang P, Barbera VM, Swift GH: A comprehensive survey of DNA-binding transcription factor gene expression in human fetal and adult organs. Gene Expr Patterns 2006, 6:678-686.

89. Kanehisa M, Goto S: KEGG: Kyoto encyclopedia of genes and genomes. Nucleic Acids Res 2000, 28:27-30.

90. Moriya Y, Itoh M, Okuda S, Yoshizawa AC, Kanehisa M: KAAS: an automatic genome annotation and pathway reconstruction server. Nucleic Acids Res 2007, 35:W182-W185.

91. Kanehisa M, Goto S, Sato Y, Kawashima M, Furumichi M, Tanabe M: Data, information, knowledge and principle: back to metabolism in KEGG. Nucleic Acids Res 2014, 42:D199-D205.

92. Taylor JS, Van de Peer Y, Meyer A: Genome duplication, divergent resolution and speciation. Trends Genet 2001, 17:299-301.

93. Jensen J: Gene regulatory factors in pancreatic development. Dev Dyn 2003, 229:176-200.

94. Habener JF, Kemp DM, Thomas MK: Minireview: transcriptional regulation in pancreatic development. Endocrinology 2005, 146:1025-1034.
95. Rudnick A, Ling TY, Odagiri H, Rutter WJ, German MS: Pancreatic beta cells express a diverse set of homeobox genes. Proc Natl Acad Sci U S A 1994, 91:12203-12207.

96. Zhong Y, Holland PWH: HomeoDB2: functional expansion of a comparative homeobox gene database for evolutionary developmental biology. Evol Dev 2011, 13:567-568.

97. Zhong YF, Butts T, Holland PWH: HomeoDB: a database of homeobox gene diversity. Evol Dev 2008, 10:516-518.

98. Finn RD, Mistry J, Schuster-Böckler B, Griffiths-Jones S, Hollich V, Lassmann T, Moxon S, Marshall M, Khanna A, Durbin R, Eddy SR, Sonnhammer ELL, Bateman A: Pfam: clans, web tools and services. Nucleic Acids Res 2006, 34:D247-D251.

99. Ballantyne JS: Jaws: the inside story. The metabolism of elasmobranch fishes. Comp Biochem Physiol B Biochem Mol Biol 1997, 118:703-742

100. Moon TW, Mommsen TP: Enzymes of intermediary metabolism in tissue of the little skate, Raja erinacea. J Exp Zool 2005, 244:9-15.

101. Walsh PJ, Kajimura M, Mommsen TP, Wood CM: Metabolic organization and effects of feeding on enzyme activities of the dogfish shark (Squalus acanthias) rectal gland. J Exp Bio/ 2006, 209:2929-2938.

102. Zendzian EN, Barnard EA: Distributions of pancreatic ribonuclease, chymotrypsin, and trypsin in vertebrates. Arch Biochem Biophys 1967, 122:699-713.

103. Prahl JW, Neurath $H$ : Pancreatic enzymes of the spiny pacific dogfish. I. Cationic chymotrypsinogen and chymotrypsin. Biochem 1966, 5:2131-2146.

104. Prahl JW, Neurath $H$ : Pancreatic enzymes of the spiny pacific dogfish. II. Procarboxypeptidase B and carboxypeptidase B. Biochem 1966, 5:4137-4145.

105. Neurath H, Lacko AG: Procarboxypeptidase A and carboxypeptidase A of the spiny Pacific dogfish (Squalus acanthias). Biochem 1970, 9:4680-4690.

106. Dong W, Fricker LD, Day R: Carboxypeptidase D is a potential candidate to carry out redundant processing functions of carboxypeptidase $E$ based on comparative distribution studies in the rat central nervous system. Neuroscience 1999, 89:1301-1317.

107. Fricker LD: Carboxypeptidase E. Annu Rev Physiol 1988, 50:309-321.

108. Brockerhoff $H$, Hoyle RJ: Hydrolysis of triglycerides by the pancreatic lipase of a skate. Biochim Biophys Acta 1965, 98:435-436.

109. Patton JS: High levels of pancreatic nonspecific lipase in rattlesnake and leopard shark. Lipids 1975, 10:562-564.

110. Patton JS, Warner TG, Benson AA: Partial characterization of the bile salt-dependent triacylglycerol lipase from the leopard shark pancreas. Biochim Biophys Acta 1977, 486:322-330.

111. Sternby B, Larsson A, Borgstrom B: Evolutionary studies on pancreatic colipase. Biochim Biophys Acta 1983, 750:340-345.

112. Sternby B, Engstrom A, Hellman U: Purification and characterization of pancreatic colipase from the dogfish (Squalus acanthius). Biochim Biophys Acta 1984, 789:159-163.

113. Bacha AB, Karray A, Daoud L, Bouchaala E, Ali MB, Gargouri Y, Ali YB: Biochemical properties of pancreatic colipase from the common stingray Dasyatis pastinaca. Lipids Health Dis 2011, 10:69.

114. Arntfield ME, van der Kooy D: $\beta$-Cell evolution: how the pancreas borrowed from the brain. Bioessays 2011, 33:582-587.

115. Upchurch $B H$, Aponte $G W$, Leiter $A B$ : Expression of peptide $Y Y$ in all four islet cell types in the developing mouse pancreas suggests a common peptide YY-producing progenitor. Development 1994, 120:245-252.

116. Jackerott $M$, Oster $A$, Larsson LI: PYY in developing murine islet cells: comparisons to development of islet hormones, NPY, and BrdU incorporation. J Histochem Cytochem 1996, 44:809-817.

117. Teitelman G, Alpert S, Polak JM, Martinez A, Hanahan D: Precursor cells of mouse endocrine pancreas coexpress insulin, glucagon and the neuronal proteins tyrosine hydroxylase and neuropeptide $Y$, but not pancreatic polypeptide. Development 1993, 118:1031-1039.

118. Schonhoff S, Baggio L, Ratineau C, Ray SK, Lindner J, Magnuson MA, Drucker DJ, Leiter AB: Energy homeostasis and gastrointestinal endocrine differentiation do not require the anorectic hormone peptide YY. Mol Cell Biol 2005, 25:4189-4199.

119. Chang C, Shen W, Rozenfeld S, Lawrence HJ, Largman C, Cleary ML: Pbx proteins display hexapeptide-dependent cooperative DNA binding with a subset of Hox proteins. Genes Dev 1995, 9:663-674. 
120. Liu A, Desai BM, Stoffers DA: Identification of PCIF1, a POZ domain protein that inhibits PDX-1 (MODY4) transcriptional activity. Mol Cell Biol 2004, 24:4372-4383.

121. Peshavaria M, Henderson E, Sharma A, Wright CV, Stein R: Functional characterization of the transactivation properties of the PDX-1 homeodomain protein. Mol Cell Biol 1997, 17:3987-3996.

122. Furlong RF, Mulley JF: ParaHox cluster evolution-hagfish and beyond. Zoolog Sci 2008, 25:955-959.

123. Furlong RF, Younger $R$, Kasahara $M$, Reinhardt $R$, Thorndyke M, Holland PWH: A degenerate ParaHox gene cluster in a degenerate vertebrate. Mol Biol Evol 2007, 24:2681-2686.

124. Holland LZ, Albalat R, Azumi K, Benito-Gutierrez E, Blow MJ, BronnerFraser M, Brunet F, Butts T, Candiani S, Dishaw LJ: The amphioxus genome illuminates vertebrate origins and cephalochordate biology. Genome Res 2008, 18:1100-1111.

125. Putnam NH, Butts T, Ferrier DEK, Furlong RF, Hellsten U, Kawashima T, Robinson-Rechavi M, Shoguchi E, Terry A, Yu K Jr: The amphioxus genome and the evolution of the chordate karyotype. Nature 2008, 453:1064-1072.

126. Le Roith $D$, Shiloach J, Roth J: Is there an earlier phylogenetic precursor that is common to both the nervous and endocrine systems? Peptides 1982, 3:211-215.

127. Larhammar D, Bergqvist CA: Ancient grandeur of the vertebrate neuropeptide $Y$ system shown by the coelacanth latimeria chalumnae. Front Neurosci 2013, 7:27.

128. Grabherr MG, Haas BJ, Yassour M, Levin JZ, Thompson DA, Amit I, Adiconis X, Fan L, Raychowdhury R, Zeng Q: Full-length transcriptome assembly from RNA-Seq data without a reference genome. Nat Biotechnol 2011, 29:644-652.

129. Conesa A, Gotz S, Garcia-Gomez JM, Terol J, Talon M, Robles M: Blast2GO: a universal tool for annotation, visualization and analysis in functional genomics research. Bioinformatics 2005, 21:3674-3676.

130. Gotz S, Garcia-Gomez JM, Terol J, Williams TD, Nagaraj SH, Nueda MJ, Robles M, Talon M, Dopazo J, Conesa A: High-throughput functional annotation and data mining with the Blast2GO suite. Nucleic Acids Res 2008 36:3420-3435.

131. Camacho C, Coulouris G, Avagyan V, Ma N, Papadopoulos J, Bealer K, Madden TL: BLAST+: architecture and applications. BMC Bioinformatics 2009, 10:421.

doi:10.1186/1471-2164-15-1074

Cite this article as: Mulley et al: Transcriptomic analysis of the lesser spotted catshark (Scyliorhinus canicula) pancreas, liver and brain reveals molecular level conservation of vertebrate pancreas function. BMC Genomics 2014 15:1074.

\section{Submit your next manuscript to BioMed Central and take full advantage of:}

- Convenient online submission

- Thorough peer review

- No space constraints or color figure charges

- Immediate publication on acceptance

- Inclusion in PubMed, CAS, Scopus and Google Scholar

- Research which is freely available for redistribution 